\title{
Application of Facies Associations, Integrated Prediction Error Filter Analysis, and Chemostratigraphy to the Organic-Rich and Siliceous Cenomanian-Turonian Sequence, Bargou Area, Tunisia: Integrated Sequence Stratigraphic Analysis
}

\author{
Mohamed Soua \\ Entreprise Tunisienne d'Activités Pétrolières, ETAP-CRDP, 4, Rue des Entrepreneurs, 2035 La Charguia II, Tunisia \\ Correspondence should be addressed to Mohamed Soua, elmohology@yahoo.fr
}

Received 2 August 2011; Revised 25 December 2011; Accepted 3 February 2012

Academic Editor: Josep Pares

Copyright (C) 2012 Mohamed Soua. This is an open access article distributed under the Creative Commons Attribution License, which permits unrestricted use, distribution, and reproduction in any medium, provided the original work is properly cited.

\begin{abstract}
Facies associations, integrated prediction error filter analysis (INPEFA) of spectral Gamma-ray data, $\mathrm{Sr} / \mathrm{Ca}$ and $\mathrm{Mn}$ chemostratigraphy, and sequence stratigraphy of the organic-rich and siliceous Cenomanian-Turonian Bahloul formation have been studied in Bargou section, located in north-central Tunisia. The studied section is subdivided into seven facies evolving from platform to basin deposits. Based on basin geometry, facies distribution, spectral Gamma-ray INPEFA curves, Sr/Ca and Mn profiles patterns, and the sequence was also subdivided into shelf margin wedge (uppermost Fahden Formation-lowermost Bahloul), basal transgressive systems tract (remainder Bahloul Formation) and early high-stand systems tract (Kef Formation). The $\mathrm{Sr} / \mathrm{Ca}$ ratios, $\mathrm{Mn}$ profile, sequence stratigraphic, and cyclostratigraphic interpretations reveal the existence of four transgressive parasequences deposited throughout $420 \mathrm{kyr}$ within the organic rich and siliceous Bahloul facies.
\end{abstract}

\section{Introduction}

The evolution of the sedimentary basins, which are considered to be filled by successive depositional sequences has proved and justified the use of the application of sequence stratigraphy concepts. The burial history of the sedimentary basin is panoply of several related factors such as subsidence, local tectonics, eustatic fluctuations, carbonate production, climatic cyclicity, as well as chemical reactions issued from several factors (temperature, pressure, density, etc.). These depositional sequences are subdivided further into systems tracts and parasequences [1-3].

The stratigraphy and sedimentology of the upper Cenomanian-lower Turonian Bahloul Formation in north-central Tunisia (Figure 1) have been the subject of numerous papers and reports (e.g., [4-8]). Recently, the recognition of the effects of sea-level changes on the stratigraphic successions led to the reinterpretation of the depositional sequences by Robaszynski et al. [9] and Maamouri et al. [10]. The main sequence (Bahloul formation) is typically controlled by the global relative sea-level rise causing the major latest Cenomanian transgression which in turn was interpreted as a combined phenomenon between a long-term sea-level rise and basin subsidence $[1,11,12]$. It must be understood that this sequence seems to be generated by enhanced plate tectonic activity and by the change in the Milankovitch frequency band (e.g., [13]) justifying climatic cycles which are detected in the sedimentary record (Figure 2). The major rise in the Cenomanian sea level was interrupted by the five-third order relative sea-level falls [1]. In the Bargou area (Figure 1(b)), the Cenomanian-Turonian deposits are mainly composed of organic-rich black shales include special siliceous beds that are rich in radiolarians. No previous sequence stratigraphic framework has been taken yet on such siliceous deposition. The aims of this paper are: (1) to present a revised stratigraphic description of the siliceous and organic-rich upper Cenomanian-lower Turonian in central Tunisia using facies association; (2) to apply new tools to sequence stratigraphy which consist of integrated prediction error filter analysis (INPEFA) of spectral Gamma-ray data 
TABLE 1: Major and trace elements normalized to Al (after Soua [14]).

\begin{tabular}{lccccccc}
\hline Elements & Average shale & Mean & Max. & Normalized elements & Average shale & Mean & Max. \\
\hline $\mathrm{SiO}_{2}$ & 58,9 & 22,02 & 106,32 & $\mathrm{Si} / \mathrm{Al}$ & 3,11 & 9,09 & 37,2 \\
$\mathrm{TiO}_{2}$ & 0,78 & 0,14 & 0,74 & $\mathrm{Ti} / \mathrm{Al}$ & 0,053 & 0,07 & 0,51 \\
$\mathrm{Al}_{2} \mathrm{O}_{3}$ & 16,7 & 2,2 & 4,48 & $\mathrm{Fe} / \mathrm{Al}$ & 0,55 & nd & nd \\
$\mathrm{Fe}_{2} \mathrm{O}_{3}$ & 6,9 & - & - & $\mathrm{Mg} / \mathrm{Al}$ & 0,18 & nd & nd \\
$\mathrm{MgO}$ & 2,6 & - & - & $\mathrm{Ca} / \mathrm{Al}$ & 0,18 & 27,07 & 58,33 \\
$\mathrm{CaO}$ & 2,2 & 44,77 & 124,35 & $\mathrm{Mn} / \mathrm{Al}$ & 96 & nd & nd \\
$\mathrm{MnO}$ & & - & - & $\mathrm{K} / \mathrm{Al}$ & 0,34 & 0,18 & 0,26 \\
$\mathrm{~K}_{2} \mathrm{O}$ & 3,6 & 0,25 & 0,5 & $\mathrm{P} / \mathrm{Al}$ & 0,008 & 0,13 & 0,59 \\
$\mathrm{P}_{2} \mathrm{O}_{5}$ & 0,16 & 0,32 & 1,14 & $\mathrm{Ba} / \mathrm{Al}$ & 66 & 193,1 & 509 \\
$\mathrm{Ba}$ & 580 & 226,73 & 722,98 & $\mathrm{Cr} / \mathrm{Al}$ & 10,2 & 32,08 & 91,42 \\
$\mathrm{Cr}$ & 90 & 36 & 138,7 & $\mathrm{Cu} / \mathrm{Al}$ & 5,1 & 27,87 & 70 \\
$\mathrm{Cu}$ & 45 & 31,79 & 107,07 & $\mathrm{Mo} / \mathrm{Al}$ & 0,15 & $\mathrm{nd}$ & nd \\
$\mathrm{Mo}$ & 1 & - & - & $\mathrm{Ni} / \mathrm{Al}$ & 7,7 & 32,59 & 70,68 \\
$\mathrm{Ni}$ & 68 & 37,6 & 162,57 & $\mathrm{Sr} / \mathrm{Al}$ & 34 & $\mathrm{nd}$ & $\mathrm{nd}$ \\
$\mathrm{Sr}$ & 300 & - & - & $\mathrm{Th} / \mathrm{Al}$ & & 1,75 & 9,28 \\
$\mathrm{Th}$ & & 1,73 & 3,74 & $\mathrm{U} / \mathrm{Al}$ & 0,42 & 1,59 & 7,7 \\
$\mathrm{U}$ & 3,7 & 1,56 & 4,84 & $\mathrm{~V} / \mathrm{Al}$ & 15 & 92,79 & 405 \\
$\mathrm{~V}$ & 130 & 104,86 & 403,542 & $\mathrm{TOC}$ & 0,2 & 2,33 & 7,53 \\
$\mathrm{TOC}$ & 0,2 & 2,33 & 7,53 & - & - & - & - \\
\hline
\end{tabular}

and $\mathrm{Sr} / \mathrm{Ca} \& \mathrm{Mn}$ chemostratigraphy (which can be useful for detecting depositional sequences and systems tracts, Table 1), documenting the facies associations and distribution in an organic-rich and siliceous setting; (3) to illustrate how the interplay of these two analyses results in the observed distribution of facies associations in the successive systems tracts; (4) to discuss the participation of eustasy and subsidence in how creating organic-rich and siliceous sedimentation.

\section{Geological Setting}

The Bargou anticlinarium, a mountainous system which stretches in a northeast-southwest direction in the northeastern part of the Tunisian hinterland (Figure 1), contains well-preserved and continuous outcrops of CenomanianTuronian sedimentary rocks. Around the Bargou anticlinarium, the Bahloul thickness is significantly variable. It may vary from $10 \mathrm{~m}$ to $40 \mathrm{~m}$ in thickness. Uniquely, in this area, the top of the Bahloul represents many Cenomanian olistolith levels [15] marking syndepositional tectonic activities [16]. Elsewhere, these synsedimentary features are represented by local slumping.

The Bargou area is connected palaeogeographically to central Tunisia geological history and is characterized by (1) emerged palaeohighs displaying gaps and discontinuities [16] and (2) subsiding zones affected by deep water sedimentation. Generally speaking, this area is dominated by N140 and N70 trend faults limiting several blocks. Cretaceous sedimentation varies on both sides. The structural evolution of the area may be summarized as follows: (1) during the late Jurassic to early Cretaceous, the area was subjected to a major extensional phase that delimited horst and graben systems
[17]. (2) In the uppermost Aptian, a regional compressional pulsation affecting the north-African platform had resulted from a transpressional scheme [18]. (3) New NNE-SSW trend anticline structures appeared attested by the Albian Fahdene Formation onlap features on the reefal aptian Serj deposits in subsurface [19] or Albian-upper Aptian unconformity in outcrops. (4) During the Albian, the geodynamic evolution is marked by the sealing of lower cretaceous structures during an extensional phase that persisted to form graben systems promoting organic-rich and siliceous strata deposition throughout upper Cenomanian to lower Turonian times. Generally speaking, in northcentral Tunisia as well as on the Pelagian Province, Cretaceous diapiric movements of Triassic salt played locally an important role in controlling C/T deposition, [20-22]. They are characterized by a marked thickness reduction and partly by the development of a detrital deposition (sandstones, conglomerates). The diapiric rise, starting from Aptian (and even before) to approximately middle Eocene was probably continuous, but it increased during periods of tectonic instability. Thus earlier diapiric movements and rise-up are superimposed to the extensional features favouring depocenters individualisations in the central parts of rim-synclines [22].

\section{Material and Methods}

The outcomes of this study are based on two outcrops, from Bargou area, Ain Zakkar (AZ), and Dir ouled yahia section (OKS), analysis, consisting of the measurement of 132 samples and their correlation with two other sections from central Tunisia. The distribution of these sections is shown in Figure 1. Field analysis includes the drawing of sedimentary 


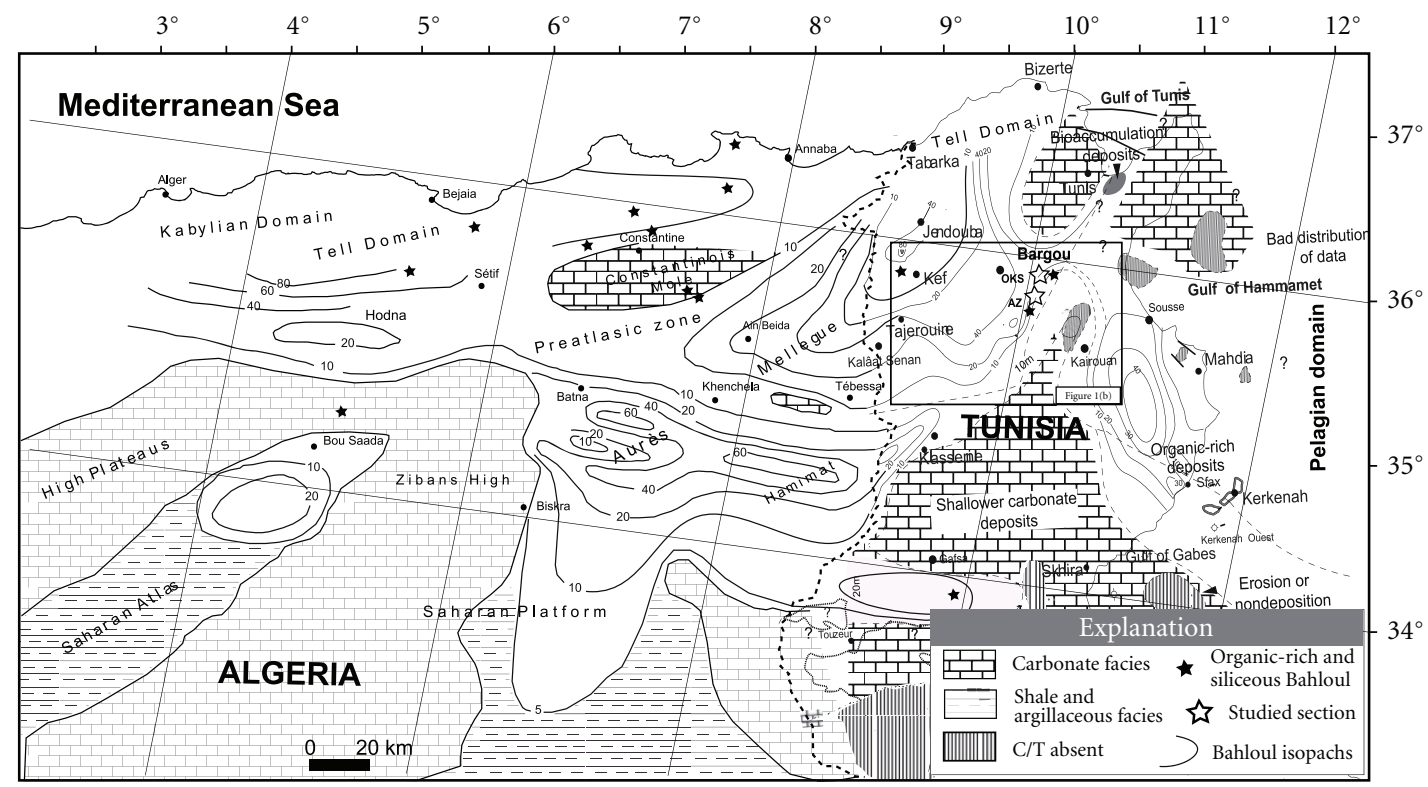

(a)

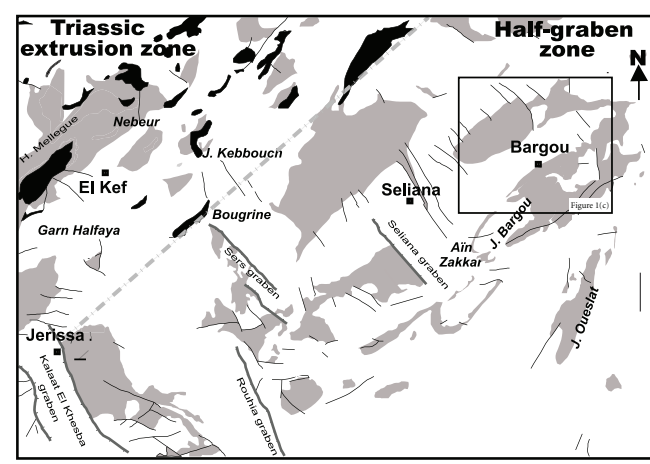

Explanation

Triassic halokinesis
$\square$ Upper cretaceous

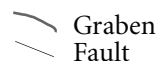

Fault

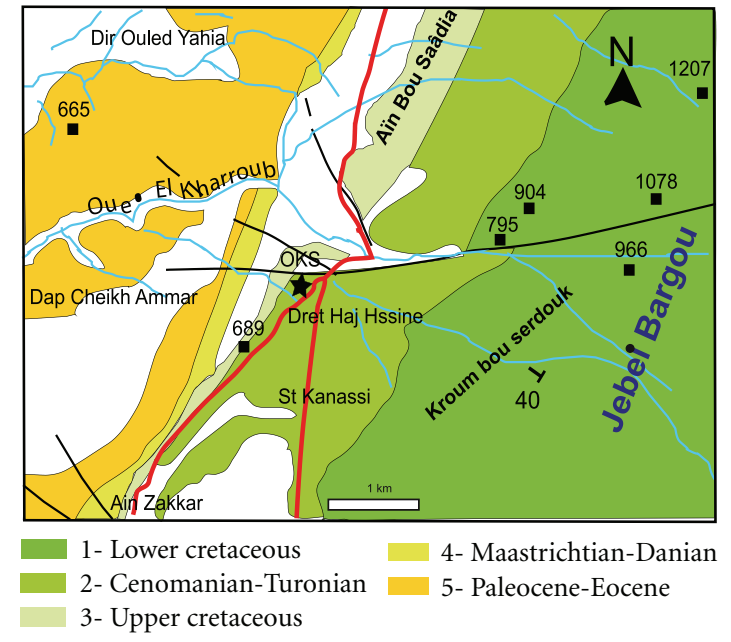

(c)

FIGURE 1: (a) Facies and thickness of the organic-rich late Cenomanian-early Turonian and age equivalent units in Tunisia and eastern Algeria superposed on the structural setting of the eastern Maghrebian Domain during the C-T transition (inferred from the palaeogeographic map). Note that the isopach trends illustrated are simplified and short-distance thickness and facies changes occur, related to the complex tectonohalokinetic palaeorelief at the time (see (b)). (b) Tectonic map of the central Tunisia Domain showing main upper cretaceous deposits and structures. (c) Geological map of the studied area showing the distribution of the two sections.

units and bounding surfaces as well as the detecting of possible facies associations, which in turn, are assessed by interpretation of depositional settings in outcrop and from petrographic studies (Figure 3). Biostratigraphic determinations and correlations for the upper Cenomanian-lower Turonian interval were made on the basis of standard foraminiferal and radiolarian biozonations in earlier studies [14, 24] (see also Figure 2). The sections were logged using portable Gammaray spectrometer model RS-230 with duration of about 2 minutes for each measurement, with a general spacing between measured points of $10 \mathrm{~cm}$. Three readings were sufficient to determine a mean value for each measurement.
The digital measurement outputs are expressed in LAS files (Table 2), including depth versus GR of each studied section (Figure 4). Integrated Prediction Error Filter Analysis curve (INPEFA) was conducted on digital data (LAS files) using CycloLog software as described by Nio et al. [23]. Major elements concentrations were determined using Mass spectrometry (ICP-AES) process and trace elements were determined using induced coupled plasma mass spectroscopy (ICP-MS) at ETAP (Table 1). In this study, Sr/Ca and Mn variation curves were determined (Figure 5) in order to check relationships with sea level fluctuation as described by Mabrouk et al. [25]. Thin sections were made in the 


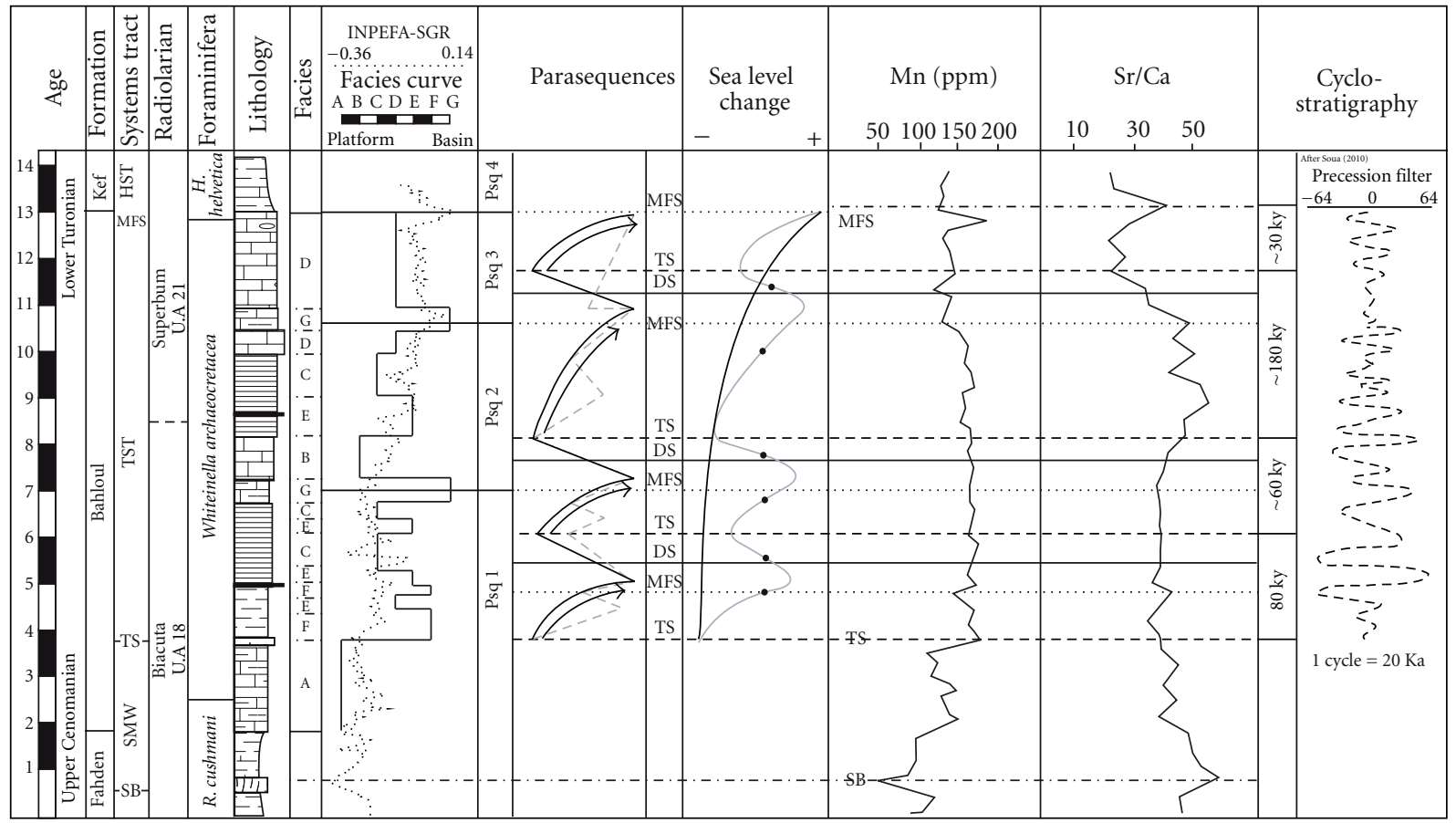

FIGURE 2: Facies curve, integrated predictive error filter of the spectral gamma ray (INPEFA-SGR), parasequences sets, Sr/Ca and Mn chemostratigraphy, global trend, and age of parasequences in Ain Zakkar section (Bargou area, central Tunisia). The cyclostratigraphy is after Soua [13].

hard limestone samples in order to analyze microfacies in the laboratory of sedimentology of the Office National des Mines.

\section{Results}

4.1. Facies Associations. The Bargou area represents special organic-rich deposits showing mixed facies composed of both calcareous and siliceous material. In this case, at the Dir ouled Yahia (OKS) and Ain Zakkar (AZ) sections the C-T transition deposition become not conform to the typical Bahloul Formation as defined by its author [8]. Facies association analysis allows distinguishing diverse types (A-G) and differs from the typical Bahloul by the Facies $\mathrm{E}$ (see Figures 2 and 6).

4.1.1. Facies A: Calcisphaeres-Rich Massive Limestone. It forms massive light grey limestones with nodular base. These calcisphaeres-rich are mainly packstone in texture and show bioturbations. They characterize the lower part of the studied C-T transition series equivalent to the typical Bahloul Formation. Among calcisphaeres, Bonetocardiella sp., Calcisphaerula sp., and Pethonella sp., are associated with (1) diversified keeled planktonic foraminifera (Rotalipora cushmani, Praeglobotruncana stephani, Dicarinella algeriana) and globular forms like whiteinellids and hedbergellids, (2) benthonic foraminifera (Textularia, Lenticulina), (3) echinoderms debris, and (4) rounded phosphate and glauconite grains that may be evidence of reworking.

4.1.2. Facies B: Pseudo-Laminated Limestone. They are both wackestone and mudstone texture (Figure 3 ). Those of wackestone texture are especially dark. In contrast those of mudstone texture are light-coloured and show frequent bioturbation marks and less varied microfauna. Similar facies are described by Layeb [29]. Within these pseudo-laminated limestones, we note the exclusive presence of globular planktonic foraminifera in organic-rich micritic matrix. This situation is sometimes interrupted by bioclastic material discharges (calcispheres, echinoderms debris) coming probably either from the platform or by the oxygenated episodes (supported also by ichnofossils presence).

4.1.3. Facies C: Laminated Black Shales. The Bahloul Formation is mainly composed of laminated black shales alternated with light marly levels. Petrographic analysis reveals that these black shales are constituted by tightened alternation composed of (1) light inframillimetric packstone laminae and (2) dark millimetric mudstone laminae.

Light Laminae. The light laminae contain abundant calcisphaeres and globular scarce biserial/triserial and trochospiral planktonic foraminiferal which may be agglomerated in aggregates. The dominant biserial and triserial, Heterohelix moremani, $H$. reussi, and Guembelitria cenomana are associated with scarce trochospiral forms belonging to whiteinellids and hedbergellids. These laminae may also contain either exclusively calcisphaeres or associated whiteinellids heterohelicids or hedbergellids. Some laminae display monospecific association.

Dark Laminae. These wackestone texture laminae display significant pellets concentration and scarce globular planktonic foraminifera. The ovoid pelletoids represent no internal structure and they correspond probably to small organicrich pellets [31]. It is assumed that they come from gelatinous 

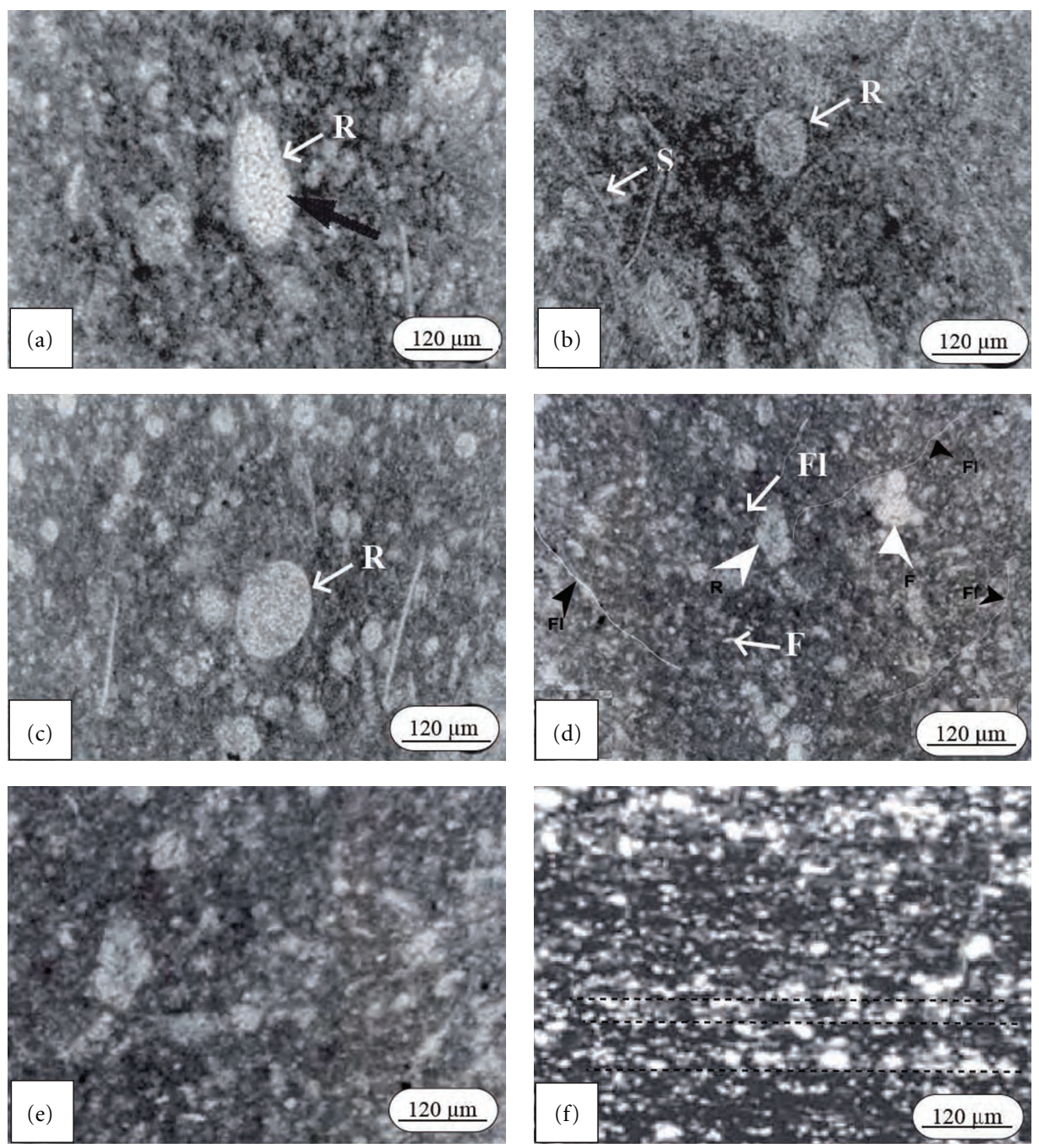

FIGURE 3: $(\mathrm{a}-\mathrm{c})$ Micrographs of a radiolarian-rich layers from the Bahloul Formation at the AZ and OKS sections showing nassellarians and spumellarians; (d) micrograph across planktonic foraminiferal-rich and filaments beds; (e) microconglomeratic level at the base of the section showing broken skeletons of diverse fauna; (f) micrograph across laminated limestone beds. Note-R: radiolarian, F: planktonic forminifer, Fl: filament, S: sponge spicule.

planktonic forms analogue to the present salps. Currently, in Mediterranean Sea, salps, and notably Salpa fusiformis can be absent during several years from the water mass, then it forms suddenly large scale population that may influence the whole pelagic community. Their diatoms-rich pellets become abundant and generate organic-rich flux involving a considerable organic matter input through the lower water mass [32].

4.1.4. Facies D: Filament-Rich Laminated Limestone. These filaments-rich laminated limestones occur in the upper part of the studied series at the OKS section. They display wackestone to packstone texture (Figure 3 ). The filaments are present as elongated and thin with imbricated and tangled arrangement enveloping sparitic elements. We do not believe that these filaments are larval planktonic stage bivalves as reported by Robaszynski et al. [33] because in our material they display several features such as tangling and overlapping. Moreover, they display heterogeneous sizes. Sometimes these light-coloured thin filaments are present as elongated or arched. Their abundance is related to that of planktonic foraminifera and defines pelagic facies [24]. All these figured elements are slightly oriented with the stratification trend. Analogous facies was documented also in Jurassic series. Within these series, similar filaments are attributed to debris of pelagic bivalves like as Picnodonta.

4.1.5. Facies E: Radiolarian-Rich Laminated Black Shales. In Bargou area, radiolarian-rich laminated black shales were reported from the OKS and AZ sections [14, 15, 24]. They occur as decimetric laminated siliceous limestone. They were labelled Silexites by Layeb and Belayouni [34] and Layeb [29]. 


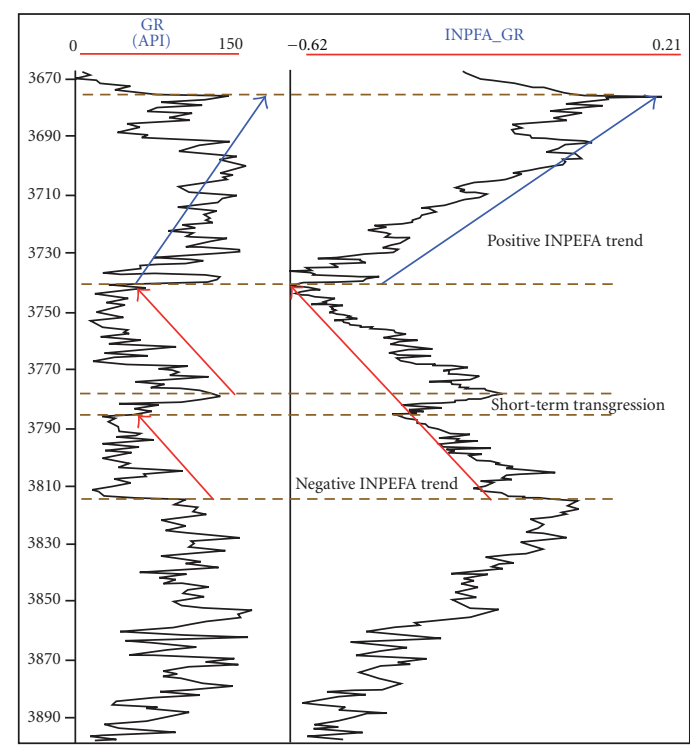

(a)

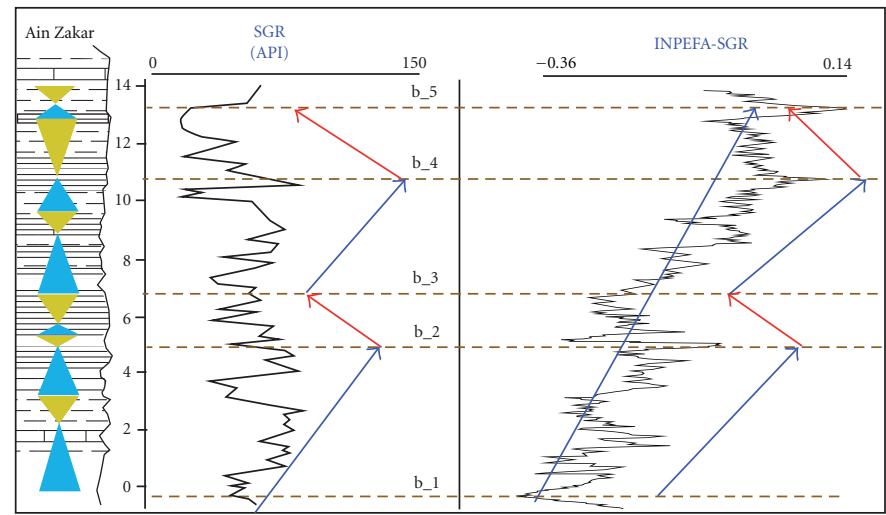

Explanation

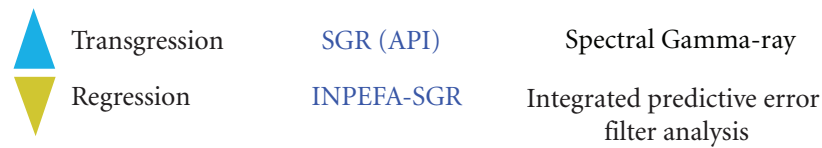

(b)

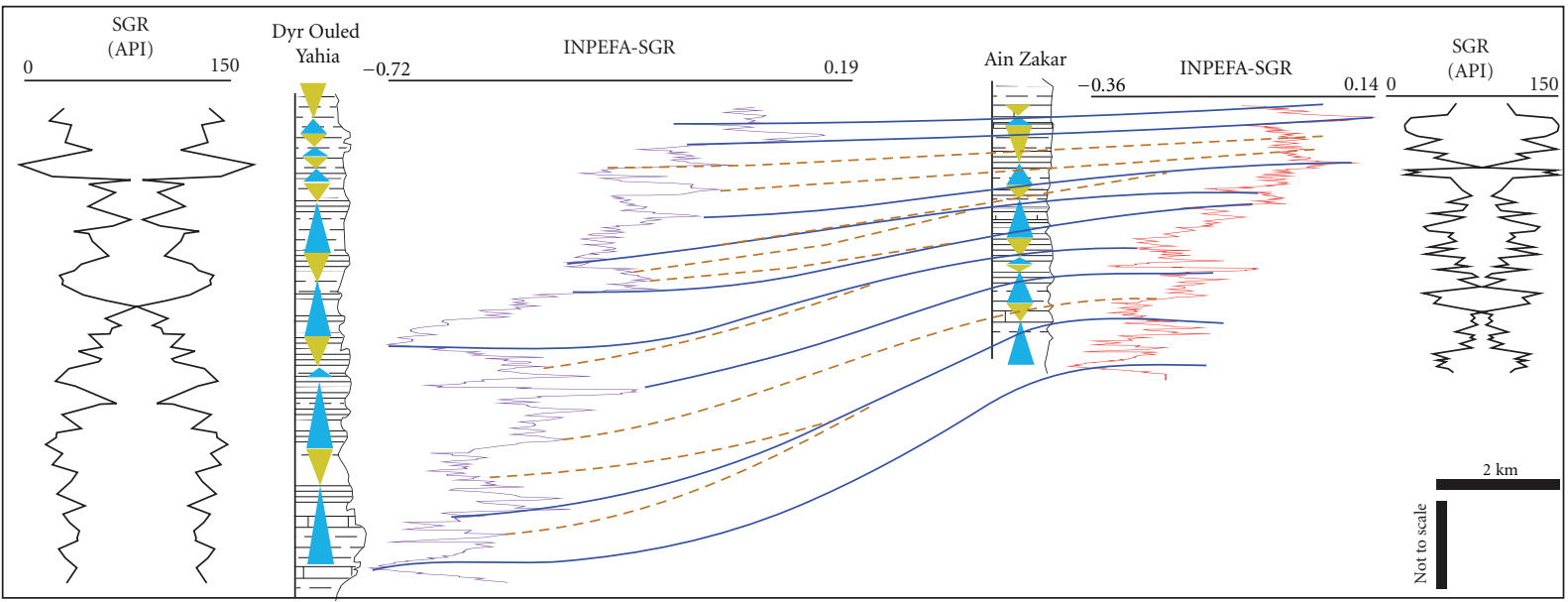

Explanation

INPEFA: Predictive error filter

- Correlation line

- - - Additional lines

(c)

FIgURE 4: Detailed presentation and correlation of the integrated predictive error filter short-term curve. (a) Example of spectral trend attribute analysis (INPEFA) of the GR $\log$ (after Nio et al. [23]). (b) Generated spectral Gamma-ray (SGR) and the related INPEFA as well as the generated package surfaces (evolving from b_1 to b_5). (c) High resolution correlation of the two studied sections using INPEFA curves.

The radiolarian-rich laminated black shales in Bargou area are formed by millimetric light wackestone and dark mudstone laminae. The light laminae display a significant siliceous radiolarian concentration, however, the dark one display a dense organic-rich pellets concentration.

4.1.6. Facies F: Dark Marls with Tiny Planktonic Globular Foraminifera. Dark marls which do not exceed $1 \mathrm{~m}$ thick are present in AZ section in the lower part of the Bahloul Formation, just above the surface of condensation. They are dark and contain dissociated tiny globular chambers of whiteinellids, hedbergellids, and Heterohelicacea (Heterohelix and Guembelitria) species within mud matrix. This facies suggests deep marine non agitated depositional pattern. In these marls, the eutrophic surface dweller Guembelitria scarcity, the benthonic foraminiferal absence and the surface dwellers whiteinellids and heterohelicids proliferation may indicate concurrent eutrophic condition at the surface sea water and anoxic condition at the sea floor [30]. The same facies (dark marls with tiny globular chambers of planktonic foraminifera) is reported from the Hammem Mellegue section, Kef area [35-37].

4.1.7. Facies G: Light Clayey Limestones. They display mudstone texture with scarce entire planktonic foraminifera having globular and keeled chambers. They are associated with rare pyritous ostracods and scarce benthic foraminifera (Lenticulina sp., Bulimina sp.). 


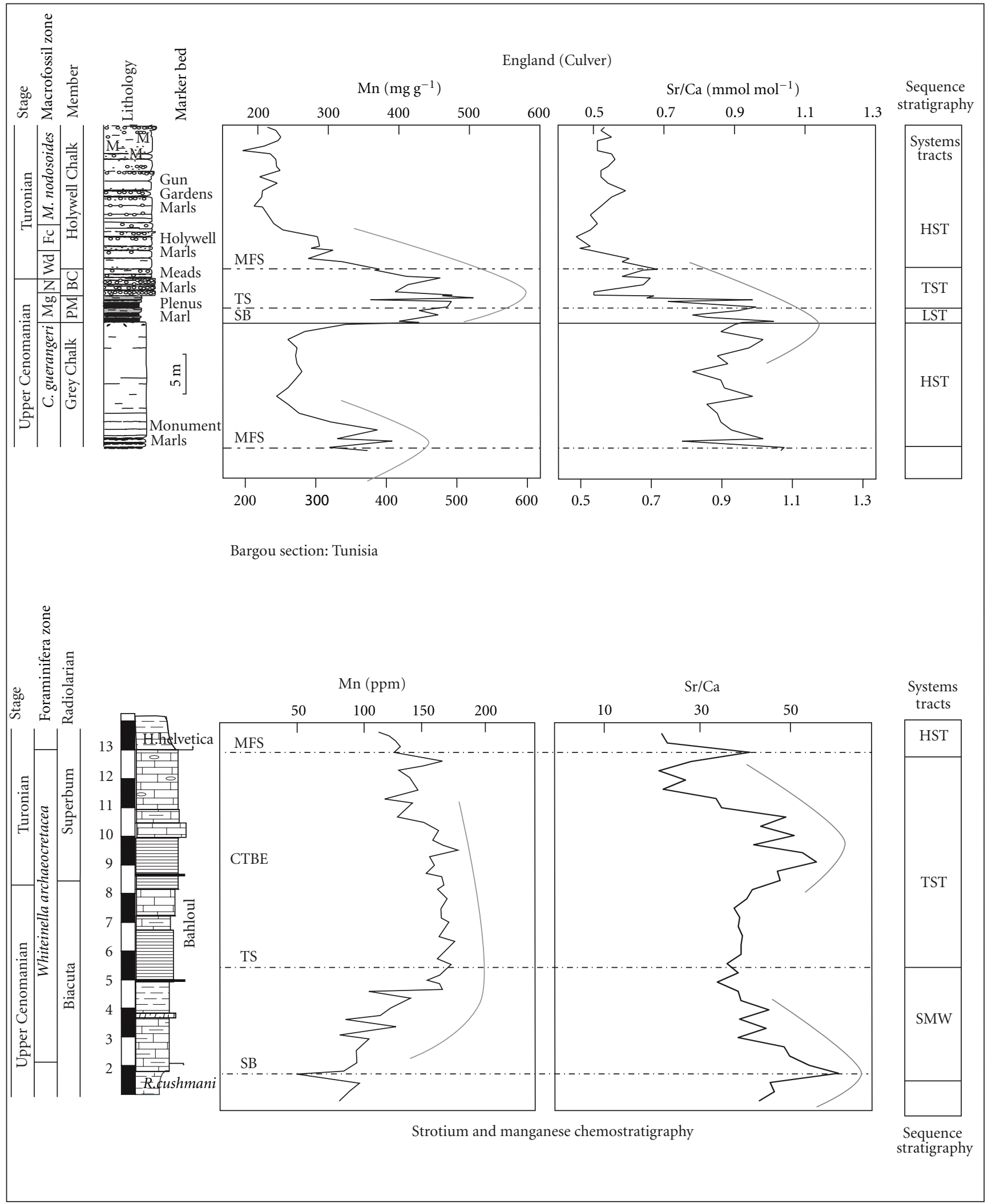

(a)

Figure 5: Continued. 


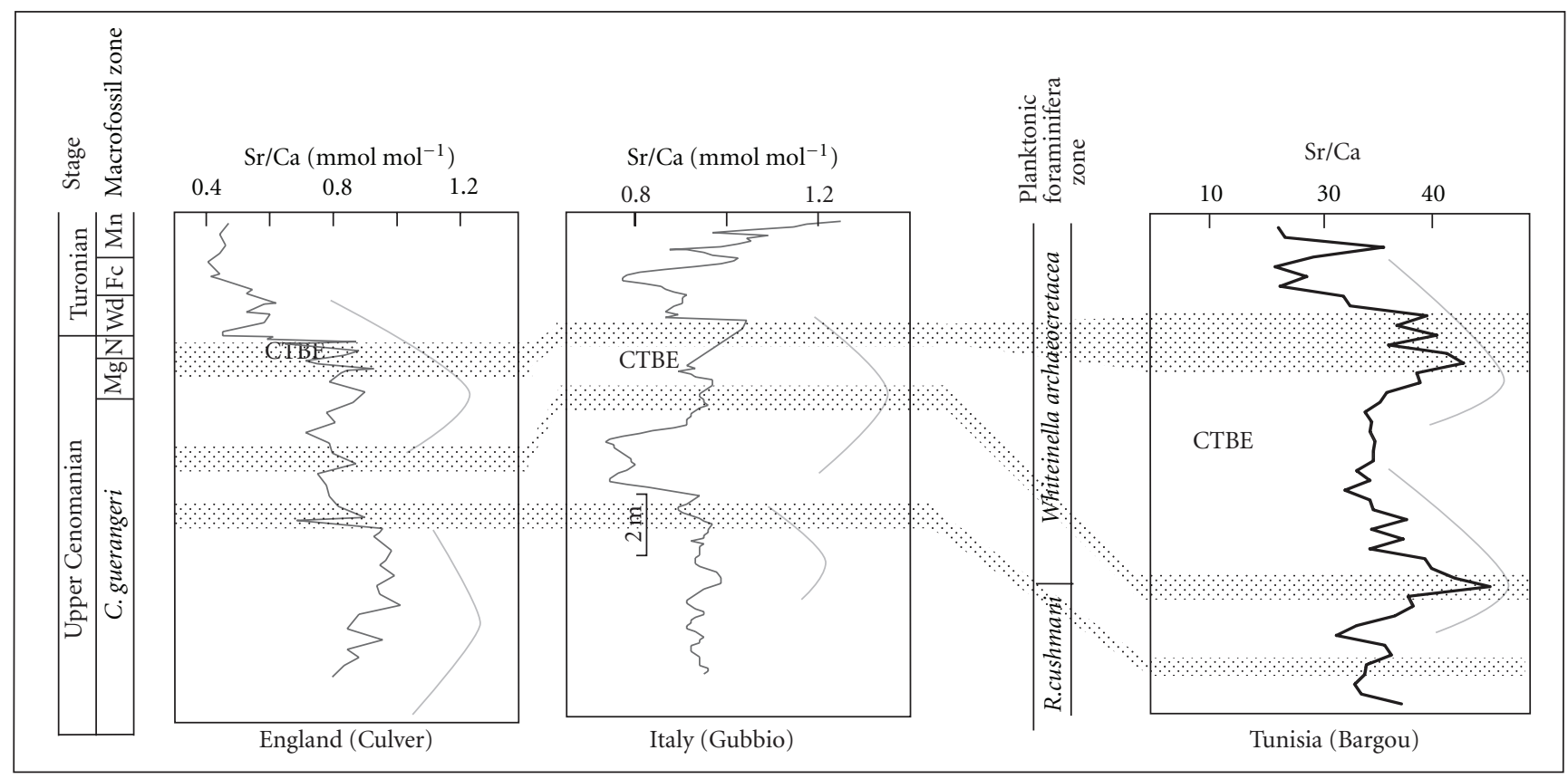

(b)

Figure 5: Stratigraphy, Mn and Sr/Ca ratio curves for the Cenomanian-Turonian transition of Culver, England [25] compared and correlated to the Ain Zakkar section (Bargou area, Tunisia). General trends in the Mn and Sr/Ca stratigraphy are indicated by solid grey curved lines. Note that $\mathrm{Sr} / \mathrm{Ca}$ and $\mathrm{Mn}$ general trends are very similar to those in Culver section. Sr/Ca maxima span the shelf margin wedge (SMW) of the Fahden and lower part of the Bahloul Formations, with maximum values around sequence boundaries. Sr/Ca values fall through transgressive systems tracts (TST) and attain minimum values in the upper part of it. However, Mn exhibits important relationships to sequences but differently from $\mathrm{Sr} / \mathrm{Ca}$, with minima around sequence boundaries and through SMW, rising values from the TS through TST, maxima around maximum flooding surfaces, and normally decreasing through HST. (b) Comparison of the C/T transition Sr/Ca stratigraphy of England (Culver) and Italy (Gubbio) (Culver section data taken from [25, 26]; Gubbio data taken from [27]). The two sections are correlated using $\mathrm{Sr} / \mathrm{Ca}$ events. Grey curves indicate the positions of $\mathrm{Sr} / \mathrm{Ca}$ ratio maxima. Sequences are after Hardenbol et al. [28]. SB: sequence boundary; TS: transgressive surface; MFS: maximum flooding surface; HST: highstand systems tract; LST: low-stand systems tract; TST: transgressive systems tract.

4.2. Integrated Prediction Error Filter Analysis Using Spectral Gamma-Ray. Generally speaking, the spectral analysis is applied to log data [38]. By that way, Nio et al. [23] described the use of an error filter in the linear prediction of the log shape to evaluate the spectral contents. The log attribute is known as the Prediction Error Filter Analysis curve (PEFA) [38]. It visualizes breaks in continuity of the spectral representation of a log. The PEFA can easily be transformed into an integrated PEFA (INPEFA) curve that is more stable and easier to interpret geologically. The log attribute is useful in high resolution sequence stratigraphy, where climatic cycles are detected in the sedimentary record. As described by Nio et al. [23], cumulative negative set of prediction error values may result as negative INPEFA trend. Negative prediction error values imply overestimation of the spectral Gamma-ray (SGR) value by the filter. Therefore, it represents a segment of the data through which the actual values of the log are less than predicted. In the case of the Bahloul SGR logs, the actual values are more carbonaceous (black shale) than predicted. Generally speaking, the same authors define negative INPEFA trend as regressive although its exact significance will be dependent on the geological context. In opposition, a positive trend in the INPEFA of the SGR logs may signify a transgressive trend.

For the purpose of this study, short-term INPEFA was used in order to detail the packages that could contain the formation. The short term INPEFA curves generally show enhanced character and usually could give a better interpretation. This is called climate stratigraphy by Nio et al. [23]. The climate stratigraphy of the Bahloul Formation, basing on the short term INPEFA-SGR curve, can display approximately four (04) stratigraphic packages (Figure 4).

The short-term INPEFA curve of the Bahloul was subdivided into five bases evolving from b_1 to b_5 (Figure 4), where $b_{-} 1$ is corresponding to the sequence boundary (SB), b_2 is corresponding to the transgressive surface (TS) and b_5 is corresponding to the maximum flooding surface (MFS). The first package shows strongly several abrupt changes of negative turning points within a general positive trend (Figure 4(b)). This short-term INPEFA-SGR curve shows C-shape character vertically (Figure 4). However, the trend pattern is still similar and correlatable and shows the synchrony of the vertical lithofacies changes and, the synchrony of fluxes of both marly or carbonaceous and even siliceous 


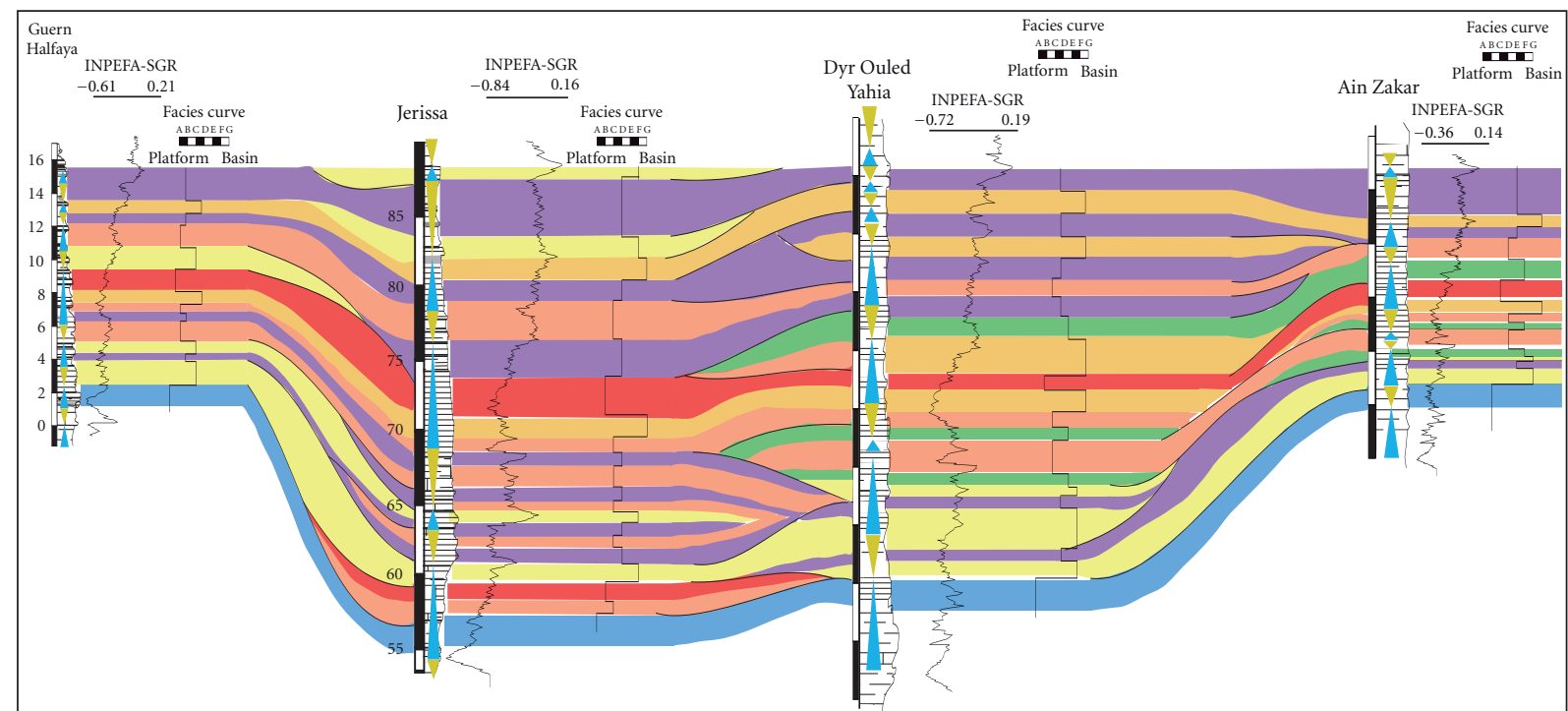
Facies G
Facies $\mathrm{F}$
Facies $\mathrm{E}$
Facies D
Facies C
Facies B
Facies A

FIGURE 6: High resolution sequence stratigraphic correlation between Bargou area (OKS and AZ sections) and central Tunisia (Jerissa and Guern Halfaya, after Soua [30]) using facies association and INPEFA-SGR.

facies where the INPEFA correlation offers a framework for analyzing lateral facies variation between the OKS and AZ sections (Figure 4(c)).

The general trend of short-term INPEFA-SGR curve of the second package situated within the b_2-b_3 interval is strongly negative correspond with the thick siliceous bed overlying the previous package. In summary four different packages have been generated by the INPEFA-SGR curve which show a general positive trend indicating a transgressive systems tract (TST). Within this curve, several peak values are corresponding to marker surfaces (SB, TS, and MFS) (Figure 4(b)).

\subsection{Sr/Ca and Mn Chemostratigraphy}

4.3.1. Sr/Ca Ratio as Indicator of Sea-Level Change. Generally speaking, high $\mathrm{Sr} / \mathrm{Ca}$ values are broadly spanning the upper parts of the shelve margin wedges (SMWs) and the high stand systems tracts (HSTs). The peak values correspond generally to sequence boundaries (SBs). It must be understood that the $\mathrm{Sr} / \mathrm{Ca}$ ratio values fall through the transgressive systems tracts (TST) intervals [25-27, 30, 39]. In our material, in AZ section (Figure 5), the Sr/Ca ratio shows peak value of 58 that coincides with the SB (Figure 5(a)). The high values are corresponding to the SMW and the upper part of the Bahloul Formation as well as the early HST (mean value $\sim 40$ ) and remain relatively constant through the lower part of the Bahloul Formation. Alternatively, it shows a significant decrease to much low $\mathrm{Sr} / \mathrm{Ca}$ values until reaching minimum values in the upper part of this systems tract $(\sim 20)$ at the top of the formation (Figures 2 and 5). Otherwise, the Sr/Ca ratio curve displays more than one short-term cycle that generally matches with the depositional sequences and matches especially with the INPEFA-SGR curve shortterms as well as the Facies curve (Figure 2). These $\mathrm{Sr} / \mathrm{Ca}$ ratio patterns were also described by Mabrouk et al. [25] concerning the $\mathrm{C} / \mathrm{T}$ transition series from Tunisian onshore and elsewhere.

4.3.2. Manganese (Mn) and Sea-Level Changes. The Mn fluctuations across each depositional sequence systems tract are not correlatable with either silicate or carbonate contents. This is maybe due to the Mn supply that was coupled with the biogenic flux (e.g., organic carbon), which must have decreased during the SMW $[25,26,37,40]$. The Mn profile increased with rising sea-level, reaching a maximum around each MFS (Figures 2 and 5), before decreasing again through the overlying Kef shales assigned to the HST.

\subsection{Vertical Evolution of Systems Tracts}

4.4.1. Shelf Margin Wedge (SMW). In the Bargou area (OKS and $\mathrm{AZ}$ sections), the SMW is represented by the uppermost part of the late Cenomanian Fahdene Formation and the overlying calcisphaeres-rich argillaceous wackestonepackstone bioturbated limestones arranged by the authors in the Bahloul Formation or pre-Bahloul deposits $[41,42]$. It is characterized by its highest abundance in calcisphaeres compared to planktonic, benthic foraminifera, bioclasts as well as, fauna mixture. This systems tract includes a microconglomeratic surface of condensation, rich in phosphate and glauconite grains. Internally, the microconglomeratic bed has discontinuous, wavy, parallel seams of glauconite-rich shale. Close inspection may also reveal clasts concentrations, ichnofossils (Zoophycos and Thalassinoides) and bioclasts. This surface is sharp and overlain by a (transgressive) lag of 


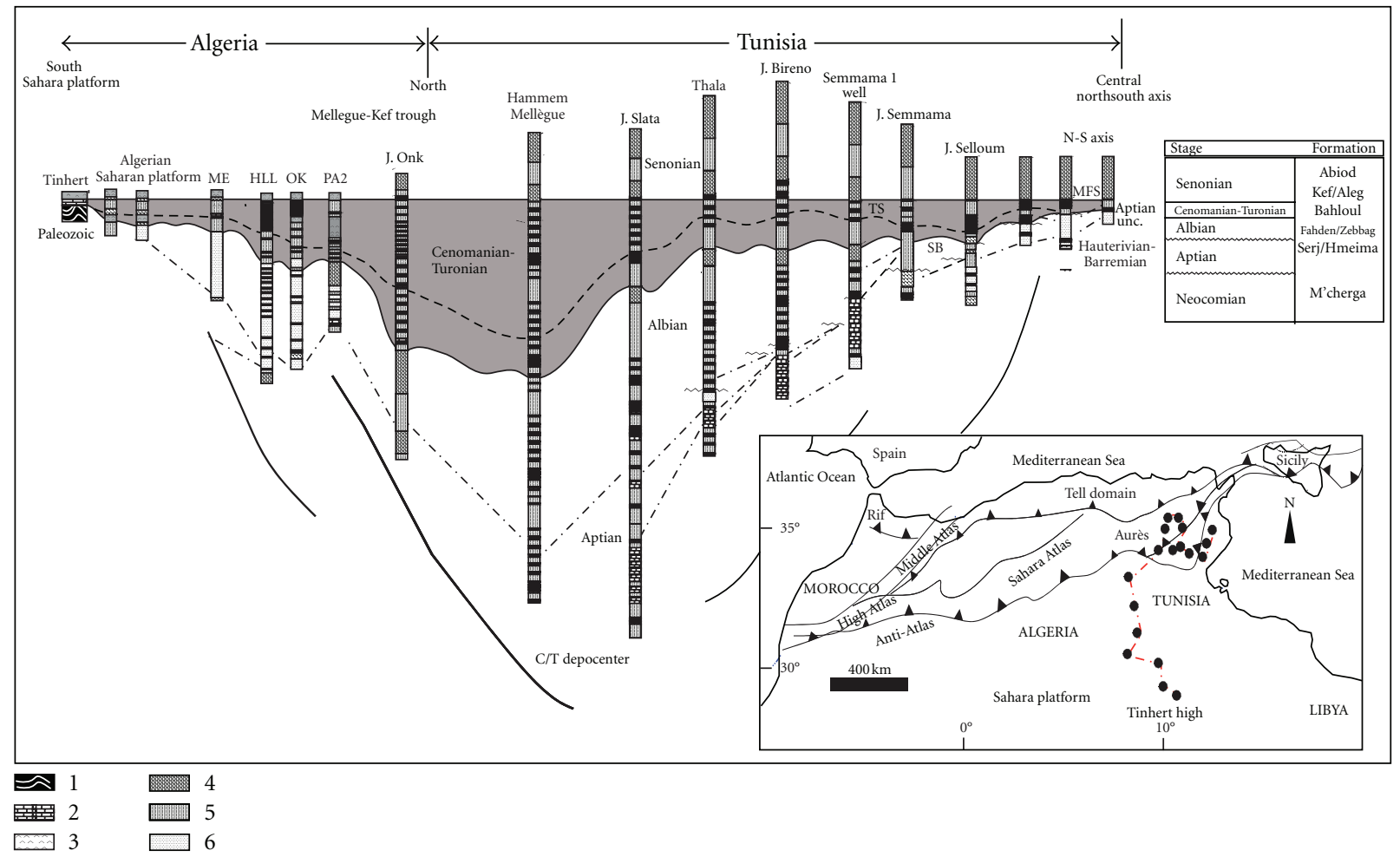

Figure 7: Tentative correlations between several Bahloul sections in Tunisia and Algeria. Datum used is MFS (top of Bahloul Formation). (1) magmatic rocks, (2) carbonate, (3) evaporites, (4) black shales, (5) marls/clays, and (6) sandstone.

reworked bioclasts (mainly echinoderms) from the neighbor platform as well as glauconite and phosphatic grains. It marks the limit between the SMW and the TST (Figure 6) and represents a fast shore line migration into the continent.

4.4.2. Transgressive Systems Tract (TST). The remainder Bahloul Formation part is considered as belonging to a transgressive systems tract (TST). Its lower boundary is represented by a transgressive surface (TS) overlying by calcareous and marly retrogradation parasequences succession (a parasequence is shallowing-upward and is bounded by a flooding surface). Within these parasequences, limestones are laminated plated organic-rich black shales encompassing, sometimes, pyrite nodules or iron oxides. These black shales contain tiny globular chambers of planktonic foraminifera (whiteinellids, herbedgellids, Heterohelicacea), radiolarian (nassallarian), and ammonites. The top of this calcareous unit, characterized by phosphate and glauconite grains abundance, suggests a maximum flooding surface (MFS). In contrast, the fissile marly levels are bioturbated. They contain a rather poor fauna of small agglutinated benthic foraminifera (e.g., neobulliminids) and weakly keeled planktonic foraminifera (e.g., dicarinellids). The MFS is situated at the top of filaments-rich limestones. It is represented by a surface of condensation, rich in grains of glauconite and phosphorite.

4.4.3. "Early" High-Stand Systems Tract (Lowermost Kef Formation). The early highstand systems tract always corresponds to retrogradational then progradational facies. In the
Bargou area like in the entire megabasin spanning the central Tunisia (Figures 6 and 7), this systems tract is represented by the lowermost Kef formation marls/limestones alternations.

\section{Discussion and Interpretation}

5.1. Lateral Evolution of Systems Tract. During the shelf margin wedge deposition, including a microconglomeratic surface of condensation, richness in phosphate and glauconite grains took place. Internally, the microconglomeratic bed has discontinuous, wavy, parallel seams of glauconite-rich shale. This surface is sharp and overlain by a lag of mainly reworked echinoderms bioclasts from the neighbor platform (Figures $1(a)$ and 7) as well as glauconite and phosphatic grains. This marks a fast shore-line migration into the continent represented by the limit between the SMW and the TST (Figures 6 and 7). This systems tract is represented generally by Facies A. Elsewhere, in the platform sequence [43-45], the SMW does not have an equivalent (Figure 7). Towards the south, the emerged Zebbag platform is subjected to sharp erosion following the fast fall relative sea level. This erosion is represented by the unconformity which overlies the limestones containing Neolobites vibrayeanus and Calycoceras sp. [45]. In the studied area, the upper part of the SMW is related to the calcareous Bahloul Formation genesis because the Fahdene Formation was originally defined as an argillaceous unit [8]. Therefore, the Bahloul Formation starts by a lithoclastic calcareous unit. Elsewhere, in Kalâat Senan area [41] and in the type locality of the Bahloul Formation [42], the same facies was assigned to the "pré-Bahloul" deposits. It is generally 
TABLE 2: Depth versus INPEFA-SGR values of the Ain Zakkar and Dyr Ouled Yahia sections.

\begin{tabular}{|c|c|c|c|}
\hline \multicolumn{2}{|c|}{ Dyr Ouled Yahia } & \multicolumn{2}{|c|}{ Ain Zakkar } \\
\hline Depth & INPEFA & Depth & INPEFA \\
\hline 25.9937 & 0.64500000 & 14.1065 & 0.26583893 \\
\hline 25.8413 & 0.64500000 & 13.9541 & 0.26583893 \\
\hline 25.6889 & 0.64500000 & 13.8017 & 0.26583893 \\
\hline 25.5365 & 0.64500000 & 13.6493 & 0.26583893 \\
\hline 25.3841 & 0.64500000 & 13.4969 & 0.26583893 \\
\hline 25.2317 & 0.64145919 & 13.3445 & 0.26509671 \\
\hline 25.0793 & 0.66285862 & 13.1921 & 0.29304966 \\
\hline 24.9269 & 0.64349511 & 13.0397 & 0.34369170 \\
\hline 24.7745 & 0.66711406 & 12.8873 & 0.31744277 \\
\hline 24.6221 & 0.66828362 & 12.7349 & 0.38196279 \\
\hline 24.4697 & 0.56525991 & 12.5825 & 0.44009400 \\
\hline 24.3173 & 0.64690752 & 12.4301 & 0.31139863 \\
\hline 24.1649 & 0.63740985 & 12.2777 & 0.28958772 \\
\hline 24.0125 & 0.71524782 & 12.1252 & 0.30730986 \\
\hline 23.8601 & 0.77351465 & 11.9728 & 0.31704103 \\
\hline 23.7077 & 0.70615673 & 11.8204 & 0.33137761 \\
\hline 23.5553 & 0.71657381 & 11.6680 & 0.34293849 \\
\hline 23.4029 & 0.55970610 & 11.5157 & 0.33623442 \\
\hline 23.2505 & 0.51239592 & 11.3633 & 0.32636670 \\
\hline 23.0981 & 0.49407311 & 11.2109 & 0.32238128 \\
\hline 22.9457 & 0.53835754 & 11.0585 & 0.32290168 \\
\hline 22.7933 & 0.54432405 & 10.9061 & 0.33707776 \\
\hline 22.6409 & 0.52704791 & 10.7537 & 0.32664013 \\
\hline 22.4885 & 0.54621253 & 10.6013 & 0.35015405 \\
\hline 22.3361 & 0.59146840 & 10.4489 & 0.36752917 \\
\hline 22.1837 & 0.43110786 & 10.2965 & 0.41308829 \\
\hline 22.0313 & 0.38688957 & 10.1441 & 0.34975962 \\
\hline 21.8789 & 0.46514914 & 9.9916 & 0.32707339 \\
\hline 21.7265 & 0.41031923 & 9.8392 & 0.31301734 \\
\hline 21.5741 & 0.44568388 & 9.6868 & 0.29369216 \\
\hline 21.4217 & 0.48813643 & 9.5344 & 0.31576101 \\
\hline 21.2693 & 0.56101978 & 9.3820 & 0.31619775 \\
\hline 21.1169 & 0.55301070 & 9.2296 & 0.30539126 \\
\hline 20.9645 & 0.58121321 & 9.0772 & 0.22945381 \\
\hline 20.8121 & 0.45475415 & 8.9248 & 0.22532759 \\
\hline 20.6597 & 0.41723888 & 8.7725 & 0.29583833 \\
\hline 20.5073 & 0.43296606 & 8.6201 & 0.30945819 \\
\hline 20.3549 & 0.44450478 & 8.4677 & 0.29509273 \\
\hline 20.2025 & 0.45840882 & 8.3153 & 0.29006810 \\
\hline 20.0501 & 0.43160168 & 8.1629 & 0.22997375 \\
\hline 19.8977 & 0.52736915 & 8.0105 & 0.17623658 \\
\hline 19.7453 & 0.54808228 & 7.8580 & 0.22440181 \\
\hline 19.5929 & 0.47296577 & 7.7056 & 0.20357850 \\
\hline 19.4405 & 0.47150725 & 7.5532 & 0.24343885 \\
\hline 19.2881 & 0.44591663 & 7.4008 & 0.21672545 \\
\hline 19.1357 & 0.40221094 & 7.2484 & 0.20948320 \\
\hline 18.9833 & 0.41769173 & 7.0960 & 0.19398237 \\
\hline
\end{tabular}

TABle 2: Continued.

\begin{tabular}{|c|c|c|c|}
\hline \multicolumn{2}{|c|}{ Dyr Ouled Yahia } & \multicolumn{2}{|c|}{ Ain Zakkar } \\
\hline Depth & INPEFA & Depth & INPEFA \\
\hline 18.8309 & 0.39151715 & 6.9436 & 0.17430740 \\
\hline 18.6785 & 0.40598255 & 6.7912 & 0.16294911 \\
\hline 18.5261 & 0.37545877 & 6.6388 & 0.15842013 \\
\hline 18.3737 & 0.39305091 & 6.4864 & 0.10313487 \\
\hline 18.2213 & 0.38909151 & 6.3340 & 0.11638473 \\
\hline 18.0689 & 0.40800814 & 6.1816 & 0.12529954 \\
\hline 17.9165 & 0.39749646 & 6.0292 & 0.13283379 \\
\hline 17.7641 & 0.34204622 & 5.8768 & 0.11110612 \\
\hline 17.6117 & 0.40302529 & 5.7244 & 0.16306310 \\
\hline 17.4593 & 0.36941421 & 5.5720 & 0.15231347 \\
\hline 17.3069 & 0.35120678 & 5.4196 & 0.14668248 \\
\hline 17.1545 & 0.45713661 & 5.2672 & 0.20678571 \\
\hline 17.0021 & 0.42445800 & 5.1148 & 0.07793188 \\
\hline 16.8497 & 0.43271535 & 4.9624 & 0.28160537 \\
\hline 16.6973 & 0.46338622 & 4.8100 & 0.20543226 \\
\hline 16.5449 & 0.46316199 & 4.6576 & 0.15300298 \\
\hline 16.3925 & 0.44233355 & 4.5052 & 0.15251638 \\
\hline 16.2401 & 0.41979804 & 4.3528 & 0.22115143 \\
\hline 16.0877 & 0.48309449 & 4.2004 & 0.17990341 \\
\hline 15.9352 & 0.36787212 & 4.0480 & 0.18227790 \\
\hline 15.7828 & 0.29659168 & 3.8956 & 0.16338533 \\
\hline 15.6304 & 0.27923951 & 3.7432 & 0.15770626 \\
\hline 15.4780 & 0.22850717 & 3.5909 & 0.18454214 \\
\hline 15.3256 & 0.25026297 & 3.4385 & 0.15557254 \\
\hline 15.1732 & 0.26302253 & 3.2860 & 0.12523092 \\
\hline 15.0208 & 0.18551864 & 3.1336 & 0.08941421 \\
\hline 14.8684 & 0.20178235 & 2.9812 & 0.10649260 \\
\hline 14.7160 & 0.22427722 & 2.8289 & 0.09628539 \\
\hline 14.5636 & 0.13545569 & 2.6765 & 0.09466668 \\
\hline 14.4113 & 0.11898032 & 2.5240 & 0.08432002 \\
\hline 14.2589 & 0.10637023 & 2.3716 & 0.12210052 \\
\hline 14.1065 & 0.05831343 & 2.2193 & 0.13791410 \\
\hline 13.9541 & 0.04770105 & 2.0669 & 0.09883344 \\
\hline 13.8017 & 0.06755763 & 1.9145 & 0.20067555 \\
\hline 13.6493 & 0.03731163 & 1.7621 & 0.12180556 \\
\hline 13.4969 & 0.03982924 & 1.6097 & 0.18512137 \\
\hline 13.3445 & 0.02728843 & 1.4572 & 0.07835971 \\
\hline 13.1921 & 0.02950794 & 1.3049 & 0.10062375 \\
\hline 13.0397 & 0.11908938 & 1.1525 & 0.05522582 \\
\hline 12.8873 & 0.14741969 & 1.0000 & 0.04591145 \\
\hline 12.7349 & 0.17254941 & & \\
\hline 12.5825 & 0.26782775 & & \\
\hline 12.4301 & 0.20322686 & & \\
\hline 12.2777 & 0.23812605 & & \\
\hline 12.1252 & 0.26814885 & & \\
\hline 11.9728 & 0.19258033 & & \\
\hline 11.8204 & 0.27236522 & & \\
\hline
\end{tabular}


TABle 2: Continued.

\begin{tabular}{|c|c|c|c|}
\hline \multicolumn{2}{|c|}{ Dyr Ouled Yahia } & \multicolumn{2}{|c|}{ Ain Zakkar } \\
\hline Depth & INPEFA & Depth & INPEFA \\
\hline 11.6680 & 0.33205011 & & \\
\hline 11.5157 & 0.19821669 & & \\
\hline 11.3633 & 0.11144277 & & \\
\hline 11.2109 & 0.09457810 & & \\
\hline 11.0585 & 0.16401912 & & \\
\hline 10.9061 & 0.43902255 & & \\
\hline 10.7537 & 0.32897953 & & \\
\hline 10.6013 & 0.27182409 & & \\
\hline 10.4489 & 0.23841358 & & \\
\hline 10.2965 & 0.26589458 & & \\
\hline 10.1441 & 0.23148772 & & \\
\hline 9.9916 & 0.36885278 & & \\
\hline 9.8392 & 0.32772460 & & \\
\hline 9.6868 & 0.26324749 & & \\
\hline 9.5344 & 0.30518988 & & \\
\hline 9.3820 & 0.26317434 & & \\
\hline 9.2296 & 0.26485610 & & \\
\hline 9.0772 & 0.24637492 & & \\
\hline 8.9248 & 0.24525662 & & \\
\hline 8.7725 & 0.28079373 & & \\
\hline 8.6201 & 0.24120334 & & \\
\hline 8.4677 & 0.31614625 & & \\
\hline 8.3153 & 0.24515400 & & \\
\hline 8.1629 & 0.22218628 & & \\
\hline 8.0105 & 0.19568930 & & \\
\hline 7.8580 & 0.16356945 & & \\
\hline 7.7056 & 0.10785320 & & \\
\hline 7.5532 & 0.16222689 & & \\
\hline 7.4008 & 0.15642428 & & \\
\hline 7.2484 & 0.12994367 & & \\
\hline 7.0960 & 0.14111858 & & \\
\hline 6.9436 & 0.13625018 & & \\
\hline 6.7912 & 0.10411001 & & \\
\hline 6.6388 & 0.13431500 & & \\
\hline 6.4864 & 0.15938333 & & \\
\hline 6.3340 & 0.14285694 & & \\
\hline 6.1816 & 0.17789436 & & \\
\hline 6.0292 & 0.21089148 & & \\
\hline 5.8768 & 0.11602156 & & \\
\hline 5.7244 & 0.22905717 & & \\
\hline 5.5720 & 0.29002400 & & \\
\hline 5.4196 & 0.30577121 & & \\
\hline 5.2672 & 0.18905913 & & \\
\hline 5.1148 & 0.25175207 & & \\
\hline 4.9624 & 0.28023261 & & \\
\hline
\end{tabular}

TABle 2: Continued.

\begin{tabular}{lcc}
\hline \multicolumn{2}{c}{ Dyr Ouled Yahia } & \multicolumn{2}{c}{ Ain Zakkar } \\
Depth & INPEFA & Depth \\
\hline 4.8100 & 0.31359986 & \\
4.6576 & 0.15221253 \\
4.5052 & 0.16220301 \\
4.3528 & 0.11452090 \\
4.2004 & 0.06719301 & \\
4.0480 & 0.09902209 \\
3.8956 & 0.07551126 \\
3.7432 & 0.15894255 \\
3.5909 & 0.21415159 \\
3.4385 & 0.09289025 \\
3.2860 & 0.05035283 \\
3.1336 & 0.19152966 \\
2.9812 & 0.17042278 \\
2.8289 & 0.15516616 \\
2.6765 & 0.14688308 \\
2.5240 & 0.10701589 \\
2.3716 & 0.06899205 \\
2.2193 & 0.03984342 \\
2.0669 & -0.00367747 \\
1.9145 & -0.00722791 \\
1.7621 & 0.06004660 \\
1.6097 & 0.10807483 \\
1.4572 & 0.14515251 \\
1.3049 & 0.20764851 \\
1.1525 & 0.22085785 \\
\end{tabular}

composed by the alternation of Facies F and D. In the neighboring section (OKS) these latter facies are much developed (Figure 4(c)) while in NW Tunisia, we note the alternation of Facies B and C (in Jerissa section, see Figure 6). The erosive base and the lenticular shape of this deposition interval suggest a channel sedimentary body. Following the the transgressive surface (Figures 2 and 6), the remainder Bahloul Formation part is considered as belonging to a transgressive systems tract (TST). The top of this calcareous unit, characterized by phosphate and glauconite grains abundance, suggests a maximum flooding surface (MFS). It is represented by a surface of condensation, rich in grains of glauconite and phosphorite. Towards the south, in the adjacent platform (Gafsa basin), as well as in the Oued Bahloul location [10], this surface is recorded by abundant earliest Turonian ammonites (e.g., Fargesia sp. and Watinoceras sp.). Nevertheless, this surface occurs when the accommodation space creation is faster than before. In this case there would be no progradation. Indeed, following the eustatic rise, this retrogradational pattern indicates that accommodation space creation exceeded sediment flux and the basin was underfilled. On the platform setting, the transgressive interval 
corresponds to the pelagic fauna limestones unit of Razgallah et al. [43]. The accommodation space creation rate is much stronger than the sedimentary input, making consequently a gradual inundation of the Zebbag platform and the pelagic facies deposition. In the studied sections, we note the development of a special Facies E (siliceous and radiolarian-rich). The richness in whiteinellids, herbedgellids, Heterohelicacea, and in radiolarian (nassallarian), as well as in ammonites, indicates a deepening depositional environment when compared to the underlying systems tract and also an enhanced primary productivity, proved by the nassellarian prolifiration. However the presence of poor fauna of small agglutinated benthic foraminifera (e.g., neobulliminids) and weakly keeled planktonic foraminifera (e.g., dicarinellids), testifies that oxygen-rich bottom waters influx may induced a welloxygenated water column when compared to dark laminated limestones. These elements confirm the spectral gamma ray and the INPEFA data generated within this study (Figure 4).

With the onset of the Kef shales (Figure 2), in the Bargou area like in the entire megabasin spanning the central Tunisia (Figures 5 and 6), the early high stand systems tract is represented by marls/limestones alternations. Towards the south (i.e., Gafsa basin) within the platform, this systems tract is represented by the subreefal carbonates of the Gattar member that recorded the filling of the space made available and making a progradational pattern. It must be understood that the Gattar carbonate formation represent the onset of the HST in the platform and biostratigraphically is dated as earliest Turonian $[43,45]$.

5.2. Climate Stratigraphy Using Gamma-Ray as Proxy of Sequence Stratigraphy. In this study, we used an integrated error filter (INPEFA) of the SGR logs analyzed on the two Bargou sections and compared to two other [30] (Figure 6). This is useful in high resolution sequence stratigraphy, where climatic cycles are detected in the sedimentary record. It is assumed that the INPEFA of the SGR log should be used for short interval [23]. The geological significance of the oscillation between positive and negative trends of the INPEFA curve is important. At small scale, as for the Bahloul Formation (which display 20 to $30 \mathrm{~m}$ ) the shift from negative trends (Figures 2 and 4), interpreted as a shallowing upward sequence (e.g., Facies $\mathrm{C}$ and $\mathrm{F}$ ) to a positive trend, interpreted as deepening upward sequence (e.g., Facies B and D) suggest that some significant change has affected the depositional system. The "shallowing upward" trend has been switched off through the major third order eustatic rise, linked to a change in the Milankovitch periodicity and in turn to climatic variation [13]. Alternatively, the switching from positive trend to negative trend, may be caused by a switching from a deepening upward sequence to a shallowing upward one and in turn the reverse effect has taken place and there is an abrupt resumption of shallower sediment deposition. The INPEFA was combined to the Facies association and remarkably all the stratigraphic surfaces and systems tracts were correlatable (see Figures 2 and 6).

5.3. Sedimentary Evolution and Palaeoenvironmental Recon- related to sea-level rise, the Sr/Ca values change which are recorded in marine carbonates of pelagic environments have been considered recently as reflecting past fluctuations of the oceanic Strontium ( $\mathrm{Sr}$ ) and calcium (Ca) budgets [39]. Large and rapid increases in seawater $\mathrm{Sr} / \mathrm{Ca}$ ratios and $\mathrm{Mn}$ profiles matches with many large Cretaceous sea level rises/falls [46]. It has been suggested that sources of Sr variations in Cretaceous carbonates can be related to changes in seawater $\mathrm{Sr} / \mathrm{Ca}$ or $\mathrm{Mn}$. It was reported that the $\mathrm{Sr} / \mathrm{Ca}$ ratios rose progressively through the mid- to late Cretaceous, a period of general eustatic sea-level rise [1, 27, 47-49]. In our material, the observed relationships between the $\mathrm{Sr} / \mathrm{Ca}$ profile and the sequence stratigraphy systems tracts are consistent with sealevel change forcing the short-term Sr/Ca record. Falling sea levels during late high-stands and low stands led to exposure of carbonate shelves and pulses of aragonite-derived Sr to the oceans. Rising sea-levels during transgression promoted renewed aragonite deposition and falling, in turn, seawater $\mathrm{Sr} / \mathrm{Ca}$ [27]. This was reversed by the development of mature carbonate platform systems (Figure 7) with lower aragonite accumulation rates during the high stands.

Our results confirm the relationship occurrence between sequence stratigraphic sytems tracts and $\mathrm{Sr} / \mathrm{Ca}$ evolution as described at Culver $[25,26]$ and elsewhere in Gubbio [27]. This is concomitant to the INPEFA-SGR and Facies association data. The Culver $\mathrm{Sr} / \mathrm{Ca}$ profile was may be compared with that of Gubbio (Italy) and Bargou (Tunisia) inspite that these three sections cannot be easily correlated biostratigraphically in detail since the biomarker among macrofossils and foraminifera are rare even absent at both Italian (Gubbio) and Tunisian (Bargou) sections seeing their siliceous facies frequency (Figure 5). In fact using $\mathrm{Sr} / \mathrm{Ca}$ profiles, ratios maxima identified within this interval transition at Culver (England) and at Gubbio (Italy) are also identifiable at Bargou (Tunisia). Mabrouk et al. [25] mentioned that breaks within the Sr/Ca curves may indicate sedimentological or diagenetic effect. At the Bargou section these breaks may correspond to intervals of silica-rich black shales comparable to the Livello Bonarelli. Increasing $\mathrm{Mn}$ in the TST (Bahloul Formation, Figures 2 and 5) might be related to increased productivity during sea-level rise promoting an increased Mn flux associated with the seafloor organic matter (authigenic manganese) [14].

\section{Conclusion}

The Cenomanian-Turonian transition is assumed to cover eustatically controlled depositional sequences which have been differentiated in all possible generated different settings in Tunisia and North Africa. It must be understood that the applicability of the sequence stratigraphy models, essentially on carbonate setting, could elucidate the vertical evolution within depositional sequences and explain the facies associations within systems tracts in the context of sea-level changes.

Thus, the studied sequence, represented by the Bahloul Formation, consists mainly of retrogradational TST involving into the progradational HST of the Kef formation, the former being composed primarily of organic-rich and siliceous black shales, the latter by alternation of marls/limestones. The Shelf margin wedge systems tract, in turn, is 
assigned to the lowermost Bahloul and the underneath Fahden formations.

Several new tools were assumed to be good proxies to sequence stratigraphy. In this paper three tools, facies association, integrated predictive error filter analysis (INPEFA) of spectral Gamma-ray, and chemostratigraphy, were used to check whether systems tracts could be illustrated in the studied sections (as they could be tools for sequence stratigraphic analysis) and what are the limits of correlation. Seven different facies associations, switching from platform to basin, were recognized within the studied Bahloul section. Indeed, these facies and lithologic units are genetically linked and integrated in a part of the third-order global sequence. Generally speaking, negative INPEFA trend is defined as regressive sequence while positive trend in the INPEFA of the SGR log would signify a transgressive sequence. Therefore, important relationships exist also between $\mathrm{Sr} / \mathrm{Ca}$ ratios profile and eustatic sea-level change. Within the CenomanianTuronian transition, Sr/Ca maxima span the upper parts of the high-stand (HST) and the shelf margin wedge (SMW) (composing the upper part of the Fahden Formation and the lower part of the siliceous Bahloul Formation), with a maximum value coinciding with the sequence boundary. $\mathrm{Sr} / \mathrm{Ca}$ values fall through the transgressive systems tract (TST) and attain minimum values in the upper part of it. Furthermore, the manganese $(\mathrm{Mn})$ exhibits important relationships to sequences but differently from $\mathrm{Sr} / \mathrm{Ca}$, with minima around sequence boundaries and through the SMW, rising values from the TS through the TST, attaining maxima around the maximum flooding surface (MFS), and normally decreasing through the HST. From this high-resolution sequence stratigraphic analysis, using facies associations, INPEFA, and Sr/Ca and Mn variations we note (1) a lateral development of some facies in the basal part of the TST, (2) the coincidence of sudden negative shift of the INPEFA with the SB and sudden positive shifts with the TS and MFS respectively, as well as the case for the $\mathrm{Sr} / \mathrm{Ca}$ and $\mathrm{Mn}$, (3) development of a special siliceous and radiolarian-rich facies (Facies E) in Bargou area, and (4) a good correlation of $\mathrm{Sr} / \mathrm{Ca}$ and $\mathrm{Mn}$ with eustatic sea level variation. In summary, the INPEFA of the spectral Gamma-ray and chemostratigraphy could be used as good tools to a detailed sequence stratigraphy.

\section{Acknowledgments}

The author would thank Professor Paul Wignall (University of Leeds, England) for providing a thorough review of an earlier draft of this work. The author is also grateful to the reviews made by two anonymous reviewers for providing constructive comments, Nigel Collins (Terrasciences Ltd.) for improving the English, and the editorial board, and especially Professor Josep M. Parés, Editor In-chief of the journal who kindly helped improving the paper.

\section{References}

[1] B. U. Haq, J. Hardenbol, and P. R. Vail, "Chronology of fluctuating sea levels since the Triassic," Science, vol. 235, no. 4793, pp. 1156-1167, 1987.
[2] P. R. Vail, "Seismic stratigraphy interpretation procedure," in Atlas of Seismic Stratigraphy, A. W. Bally, Ed., vol. 27, pp. 1-10, American Association of Petroleum Geologists, 1987.

[3] J. C. van Wagoner, R. M. Mitchum, K. M. Campion, and V. D. Rahmanian, "Siliciclastic sequence stratigraphy in well logs, cores, and outcrops: concepts for high-resolution correlation of time and facies," American Association of Petroleum Geologists, Methods in Exploration Series, vol. 7, p. 55, 1990.

[4] L. Pervinquière, Étude géologique de la Tunisie centrale, Thèse de docteur, Paris, France, 1903.

[5] Berthe, "Stratigraphie du Crétacé moyen et supérieur de la Tunisie," rapport inédit SEREPT, 1949.

[6] E. Schijfsma, "La position stratigraphique de Globotruncana helvetica Bolli en Tunisie," Micropaleontology, vol. 1, pp. 321334, 1955.

[7] P. F. Burollet, A. Dumestre, D. Keppel, and A. Salvador, "Unités stratigraphiques en Tunisie centrale," in Proceedings of the 19 ème Congrès de Géologie, Alger, 1952.

[8] P. F. Burollet, "Contribution a l'étude stratigraphique de la Tunisie centrale," Annales des Mines et de la Geologie, no. 18, p. 350, 1956.

[9] F. Robaszynski, M. Caron, C. Dupuis et al., "A tentative integrated stratigraphy in the Turonian of Central Tunisia: formations, zones and sequential stratigraphy in the Kalaat Senan area," Bulletin des Centre de Recherches ExplorationProduction Elf-Aquitaine, vol. 14, pp. 213-384, 1990.

[10] A. L. Maamouri, D. Zaghbib-Turki, M. F. Matmati, M. Chikhaoui, and J. Salaj, "La formation bahloul en tunisie centroseptentrionale: variations latérales, nouvelle datation et nouvelle interprétation en terme de stratigraphie séquentielle," Journal of African Earth Sciences, vol. 18, no. 1, pp. 37-50, 1994.

[11] J. Hardenbol, M. Caron, F. Amédro, C. Dupuis, and F. Robaszynski, "The Cenomanian-Turonian boundary in central Tunisia in the context of a sequence-stratigraphic interpretation," Cretaceous Research, vol. 14, no. 4-5, pp. 449-454, 1993.

[12] S. Luning, S. Kolonic, E. M. Belhaj et al., "An integrated depositional model for the Cenomanian-Turonian organic-rich strata in North Africa," Earth Science Reviews, vol. 64, no. 12, pp. 51-117, 2004.

[13] M. Soua, "Time series analysis (orbital cycles) of the uppermost Cenomanian-Lower Turonian sequence on the southern Tethyan margin using foraminifera," Geologica Carpathica, vol. 61, no. 2, pp. 111-120, 2010.

[14] M. Soua, "Siliceous and organic-rich sedimentation during the Cenomanian-Turonian Oceanic Anoxic Event (OAE2) on the northern margin of Africa: an evidence from the Bargou area," Arabian Journal of Geosciences. In press.

[15] M. Soua, D. Zaghbib-Turki, and L. O’Dogherty, "Radiolarian biotic responses to the Latest Cenomanian global event across the southern Tethyan margin (Tunisia)," in Proceeding of the 10th Exploration and Production Conference, vol. 26, pp. 195216, 2006.

[16] M. M. Turki, Polycinématique et contrôle sédimentaire associés sur la cicatrice de Zaghouan-Nebhana, Thèse Doctorat es Sience, Tunis, 1985.

[17] C. Martinez and R. Truillet, "Évolution structurale et paléogéographie de la Tunisie," Memoria de la Societa Italiana de Geologia, vol. 38, pp. 35-45, 1987.

[18] N. Ben Ayed and C. Viguier, "Interprétation structurale de la Tunisie atlasique," Comptes Rendus de l'Académie des Sciences, vol. 292, pp. 1445-1448, 1981.

[19] F. Messaoudi and F. Hammouda, "Evènement structuraux et types de pièges dans l.offshore Nord- Est de la Tunisie," in 
Proceedings of the 4th Tunisian Petroleum Exploration Conference, pp. 55-64, Tunis, 1994.

[20] M. Patriat, N. Ellouz, Z. Dey, J. M. Gaulier, and H. Kilani, “The Hammamet, Gabès and Chotts basins (Tunisia): a review of the subsidence history," Sedimentary Geology, vol. 156, no. 14, pp. 241-262, 2003.

[21] M. Soua and N. Tribovillard, "Modèle de sédimentation au passage Cénomanien /Turonien pour la formation Bahloul en Tunisie," Comptes Rendus Geoscience, vol. 339, no. 10, pp. 692701, 2007.

[22] M. Soua, O. Echihi, M. Herkat et al., "Structural context of the paleogeography of the Cenomanian-Turonian anoxic event in the eastern Atlas basins of the Maghreb," Comptes Rendus Geoscience, vol. 341, no. 12, pp. 1029-1037, 2009.

[23] S. D. Nio, J. Brouwer, D. Smith, M. Jong, and A. Böhm, "Spectral trend attribute analysis: applications in the stratigraphic analysis of wireline logs," First Break, vol. 23, pp. 71-75, 2005.

[24] M. Soua, "Biostratigraphie de haute résolution des foraminifères planctoniques du passage Cénomanien Turonien et impact de l.événement anoxique EAO-2 sur ce groupe dans la marge sud de la Téthys, exemple régions de Jerissa et Bargou," Mémoir de Mastère, Université de Tunis El Manar, 2005.

[25] A. Mabrouk, I. Jarvis, A. Murphy et al., "Regional to global correlations of Cenomanian to Eocene sediments: new insights to chemostratigraphic interpretations," in Proceedings of the 10th Exploration and Production Conference, vol. 26, pp. 26-45, 2006.

[26] A. M. Murphy, Sediment and groundwater geochemistry of the chalk in Southern England, PhD Thesis, Kingston University, 1998.

[27] H. M. Stoll and D. P. Schrag, "Sr/Ca variations in Cretaceous carbonates: relation to productivity and sea level changes," Palaeogeography, Palaeoclimatology, Palaeoecology, vol. 168, pp. 311-336, 2001.

[28] J. Hardenbol, J. Thierry, M. B. Farley, T. Jacquin, P.-C. De Graciansky, and P. R. Vail, "Cretaceous sequence chronostratigraphy," in Mesozoic and Cenozoic Sequence Stratigraphy of European Basins, P.-C. De Graciansky, J. Hardenbol, T. Jacquin, and P. R. Vail, Eds., vol. 60, Society of Economic Paleontologists and Mineralogists, Tulsa, Okla, USA, 1998.

[29] M. Layeb, Étude géologique, géochimique et minéralogique, régionale, des faciès riches en matière organique de la formation Bahloul d'âge Cénomano-Turonien dans le domaine de la Tunisie Nord-Centrale, Thèse docteur, Tunis, 1990.

[30] M. Soua, Le Passage Cénomanien-Turonien en Tunisie: biostratigraphie, chimiostratigraphie, cyclostratigraphie et stratigraphie séquentielle, Ph.D. thesis, Université de Tunis El Manar, Tunisia, 2011.

[31] B. H. Purser, Sédimentation et Diagenèse des Carbonates Néritiques Récents, Tome 1, Editions Technip, Paris, France, 1980.

[32] P. Morand and S. Dallot, "Variations annuelle et pluriannuelles de quelques espèces du macroplancton cotier de la Mer Ligure (1898-1914)," Rapport Commission International pour l'Exploration Scientifique de la Mer Mediterranee, vol. 29, pp. 295-297, 1985.

[33] F. Robaszynski, F. Amédro, and M. Caron, "La limite Cénomanien-Turonien et la Formation Bahloul dans quelques localités de Tunisie Centrale," Cretaceous Research, vol. 14, no. 4-5, pp. 477-486, 1993.

[34] M. Layeb and H. Belayouni, "La formation Bahloul au Centre et au Nord de la Tunisie un exemple de bonne Roche mère de pétrole à fort intérêt pétrolier," Mémoires de l'ETAP, no. 3, pp. 489-503, 1989.
[35] A. J. Nederbragt and A. Fiorentino, "Stratigraphy and palaeoceanography of the Cenomanian-Turonian Boundary event in Oued Mellegue, north-western Tunisia," Cretaceous Research, vol. 20, no. 1, pp. 47-62, 1999.

[36] M. Soua, D. Zaghbib-Turki, and N. Tribovillard, "Riverine influxes, warm and humid climatic conditions during the latest Cenomanian-early Turonian Bahloul deposition," in Proceeding of the 10th Exploration and Production Conference, vol. 27, pp. 201-212, 2008.

[37] M. Soua, D. Zaghbib-Turki, H. Jemia, J. Smaoui, and A. Boukadi, "Geochemical record of the Cenomanian-Turonian anoxic event in Tunisia: is it correlative ans isochronous to the biotic signal?" Acta Geologica Sinica, vol. 85, no. 6, pp. 13101335, 2011.

[38] P. C. H. Veeken, Seismic Stratigraphy, Basin Analysis and Reservoir Characterisation, Elsevier, Amsterdam, The Netherlands, 2006.

[39] A. Ando, H. Kawahata, and T. Kakegawa, "Sr / Ca ratios as indicators of varying modes of pelagic carbonate diagenesis in the ooze, chalk and limestone realms," Sedimentary Geology, vol. 191, no. 1-2, pp. 37-53, 2006.

[40] H. M. Stoll and D. P. Schrag, "High-resolution stable isotope records from the upper cretaceous rocks of Italy and Spain: glacial episodes in a greenshouse planet?" Bulletin of the Geological Society of America, vol. 112, no. 2, pp. 308-319, 2000.

[41] H. Accarie, F. Robaszynski, F. Amédro, and M. Caron, "Stratigraphie événementielle au passage Cénomanien-Turonien dans le secteur occidental de la plateforme de Tunisie centrale (Formation Bahloul, région Kalaat Senen)," in Proceedings of 40 ththe Annales des Mines et de la Géologie, pp. 63-80, les Septièmes Journées de la Géologie Tunisienne, Tunis, 1999.

[42] M. Caron, S. Dall'Agnolo, H. Accarie et al., "High-resolution stratigraphy of the Cenomanian-Turonian boundary interval at Pueblo (USA) and wadi Bahloul (Tunisia): stable isotope and bio-events correlation," Geobios, vol. 39, no. 2, pp. 171200, 2006.

[43] S. Razgallah, J. Philip, G. Thomel et al., "La limite Cénomanien-Turonien en Tunisie centrale et méridionale: biostratigraphie et paléoenvironnements," Cretaceous Research, vol. 15, no. 5, pp. 507-533, 1994.

[44] H. Abdallah and C. Meister, "The Cenomanian-Turonian boundary in the Gafsa-Chott area (southern part of central Tunisia): biostratigraphy, palaeoenvironments," Cretaceous Research, vol. 18, no. 2, pp. 197-236, 1997.

[45] H. Abdallah, S. Sassi, C. Meister, and R. Souissi, "Sequence stratigraphy and paleogeography at the Cenomanian-Turonian boundary in the Gafsa-Chotts region, central Tunisia," Cretaceous Research, vol. 21, no. 1, pp. 35-106, 2000.

[46] H. M. Stoll and D. P. Schrag, "Evidence for glacial control of rapid sea level changes in the early Cretaceous," Science, vol. 272, pp. 1771-1774, 1996.

[47] M. Renard, "Géochimie des Carbonates Pélagiques. Mis en Évidence des Fluctuations de la Composition des Eaux Océaniques depuis $140 \mathrm{Ma}$," Essai de Chimiostratigraphie. Doc. BRGM, 85, p. 650, 1985.

[48] J. M. Hancock, "Sea-level changes in the British region during the Late Cretaceous," Proceedings of the Geologists Association, vol. 100, no. 4, pp. 565-594, 1989.

[49] J. M. Hancock, "Transatlantic correlations in the CampanianMaastrichtian stages by eustatic changes of sea-level," High Resolution Stratigraphy, pp. 241-256, 1993. 

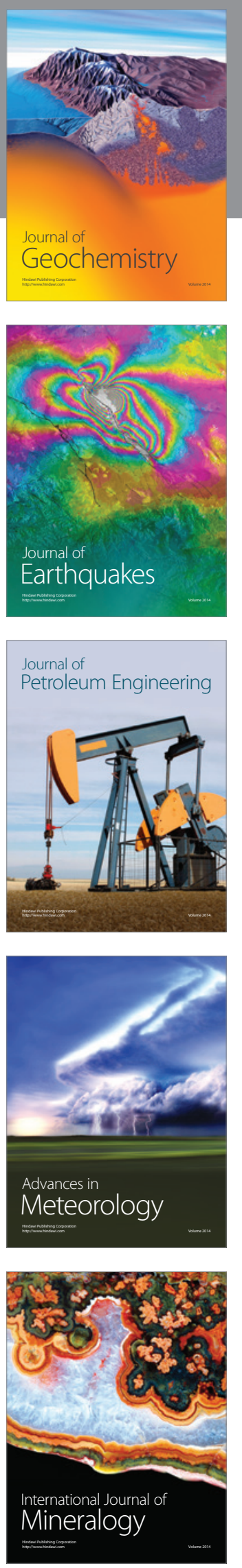
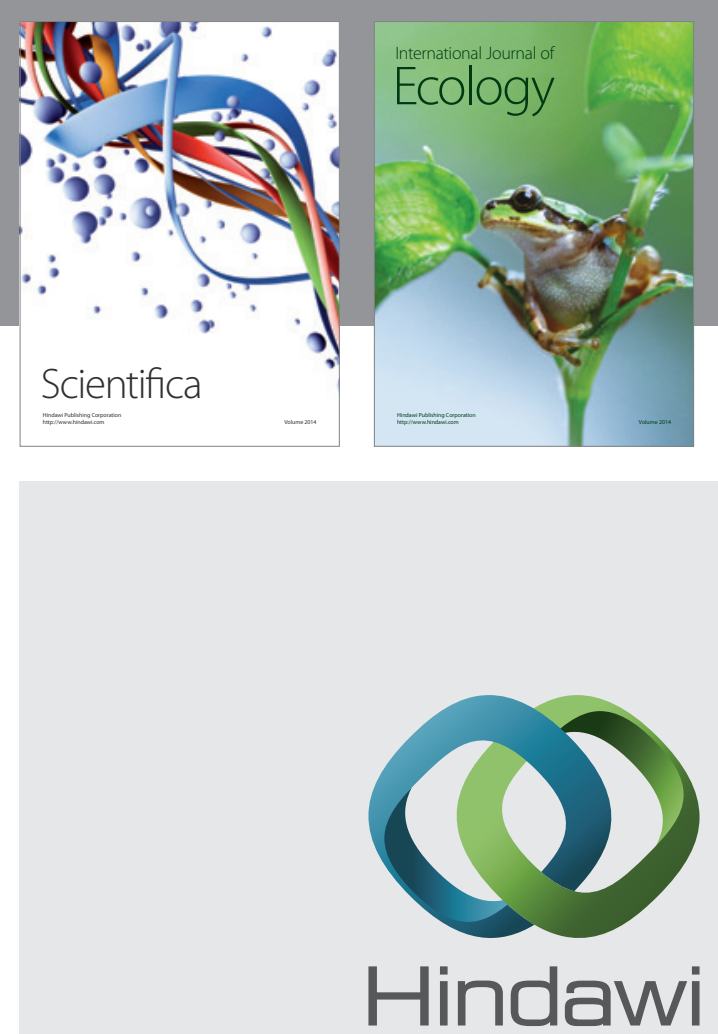

Submit your manuscripts at http://www.hindawi.com
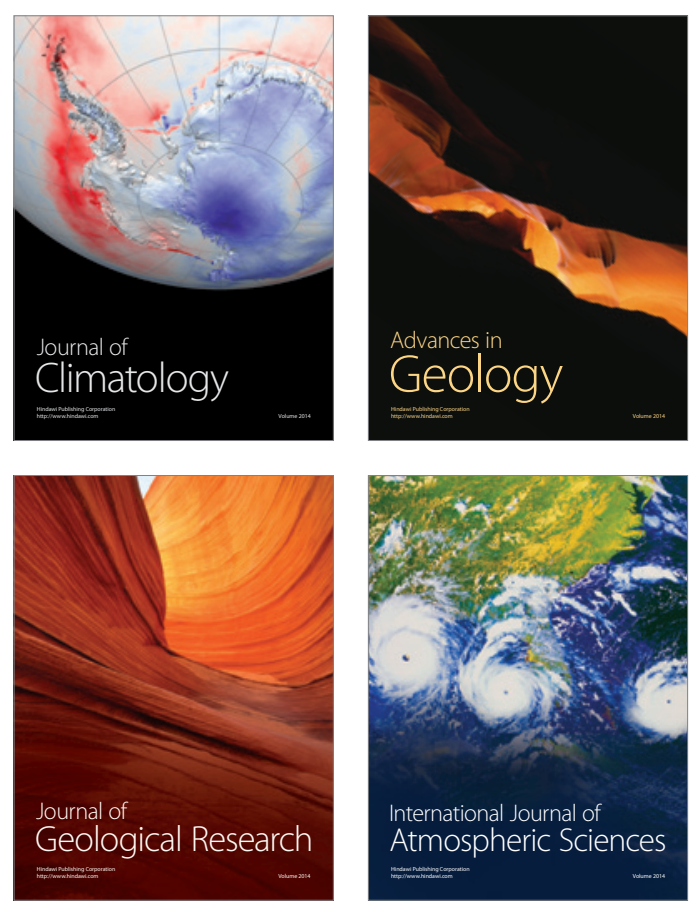
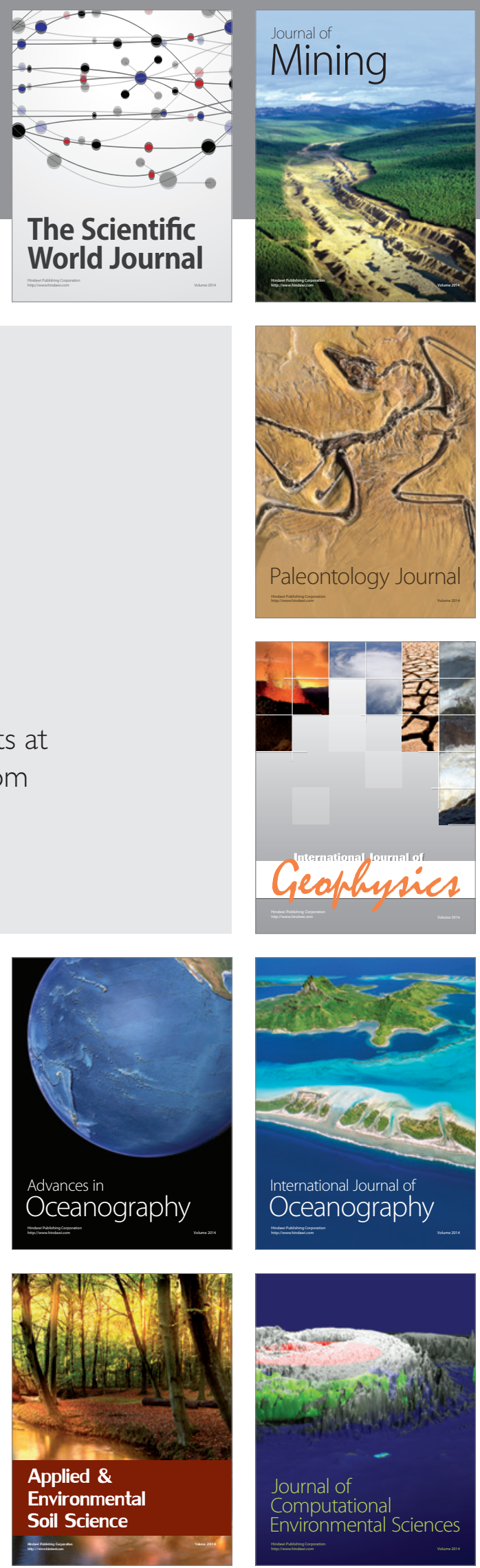